\title{
Chemical composition and sources of coastal marine aerosol particles during the 2008 VOCALS-REx campaign
}

\author{
Y.-N. Lee ${ }^{1}$, S. Springston ${ }^{1}$, J. Jayne ${ }^{2}$, J. Wang ${ }^{1}$, J. Hubbe ${ }^{3}$, G. Senum ${ }^{1}$, L. Kleinman ${ }^{1}$, and P. H. Daum ${ }^{1}$ \\ ${ }^{1}$ Atmospheric Sciences Division, Brookhaven National Laboratory, Upton, NY 11973, USA \\ ${ }^{2}$ Aerodyne Research Inc., Bellerica, MA 01821, USA \\ ${ }^{3}$ Pacific Northwest National Laboratory, P.O. Box 999, K8-88, Richland, WA 99352, USA
}

Correspondence to: P. H. Daum (phdaum@bnl.gov)

Received: 3 September 2013 - Published in Atmos. Chem. Phys. Discuss.: 9 October 2013

Revised: 26 March 2014 - Accepted: 5 April 2014 - Published: 23 May 2014

\begin{abstract}
The chemical composition of aerosol particles $\left(D_{\mathrm{p}} \leq 1.5 \mu \mathrm{m}\right)$ was measured over the southeast Pacific Ocean during the VAMOS (Variability of the American Monsoon Systems) Ocean-Cloud-Atmosphere-Land Study Regional Experiment (VOCALS-Rex) between 16 October and 15 November 2008 using the US Department of Energy (DOE) G-1 aircraft. The objective of these flights was to gain an understanding of the sources and evolution of these aerosols, and of how they interact with the marine stratus cloud layer that prevails in this region of the globe. Our measurements showed that the marine boundary layer (MBL) aerosol mass was dominated by non-sea-salt $\mathrm{SO}_{4}^{2-}$, followed by $\mathrm{Na}^{+}, \mathrm{Cl}^{-}$, Org (total organics), $\mathrm{NH}_{4}^{+}$, and $\mathrm{NO}_{3}^{-}$, in decreasing order of importance; $\mathrm{CH}_{3} \mathrm{SO}_{3}^{-}$(MSA), $\mathrm{Ca}^{2+}$, and $\mathrm{K}^{+}$rarely exceeded their limits of detection. Aerosols were strongly acidic with a $\mathrm{NH}_{4}^{+}$to $\mathrm{SO}_{4}^{2-}$ equivalents ratio typically $<0.3$. Sea-salt aerosol (SSA) particles, represented by $\mathrm{NaCl}$, exhibited $\mathrm{Cl}^{-}$deficits caused by both $\mathrm{HNO}_{3}$ and $\mathrm{H}_{2} \mathrm{SO}_{4}$, but for the most part were externally mixed with particles, mainly $\mathrm{SO}_{4}^{2-}$. SSA contributed only a small fraction of the total accumulation mode particle number concentration. It was inferred that all aerosol species (except SSA) were of predominantly continental origin because of their strong land-to-sea concentration gradient. Comparison of relative changes in median values suggests that (1) an oceanic source of $\mathrm{NH}_{3}$ is present between $72^{\circ} \mathrm{W}$ and $76^{\circ} \mathrm{W}$, (2) additional organic aerosols from biomass burns or biogenic precursors were emitted from coastal regions south of $31^{\circ} \mathrm{S}$, with possible cloud processing, and (3) free tropospheric (FT) contributions to MBL gas and aerosol concentrations were negligible. The very low levels of $\mathrm{CH}_{3} \mathrm{SO}_{3}^{-}$observed as well as the cor-
\end{abstract}

relation between $\mathrm{SO}_{4}^{2-}$ and $\mathrm{NO}_{3}^{-}$(which is thought primarily anthropogenic) suggest a limited contribution of DMS to $\mathrm{SO}_{4}^{2-}$ aerosol production during VOCALS.

\section{Introduction}

The southeast Pacific (SEP) region off the coast of Chile and Peru is home to the largest marine stratocumulus cloud deck on the globe. Such decks are typically found on the eastern edges of oceans, and play an important role in the climate system (Wood, Scientific Program Overview, http://www. eol.ucar.edu/projects/vocals/; Wood, et al., 2011; Bretherton et al., 2010). The VAMOS ${ }^{1}$ Ocean-Cloud-Atmosphere-Land Study-Regional Experiment (VOCALS-Rex) campaign, referred to as VOCALS in this work, was designed to collect observational data to help understand the structure of marine stratocumulus clouds, their radiative properties, and sources of marine aerosol particles that maintain and interact with clouds in the SEP (Wood et al., 2011).

Because aerosol particles impact cloud microphysical properties, a major effort of VOCALS was focused on characterizing aerosol particles in terms of size distribution, mass concentrations, and chemical composition so that their sources, evolution, and interactions with clouds could be investigated. In the VOCALS region, the atmospheric system that governs the marine stratocumulus in the SEP is strongly coupled to the ocean and the land whereby the

\footnotetext{
${ }^{1}$ VAMOS stands for Variability of the American Monsoon Systems.
} 
Andes mountain range forces the predominantly zonal air flow northward along the coast. This highly uniform wind field advects continental emissions from the narrow Chilean coastal regions into the MBL, and intensifies upwelling enhancing productivity with possible increased emission of organic compounds including dimethylsulfide (DMS) (cf., O'Dowd, 2004). Satellite data show a strong increase in the cloud droplet effective radius with distance from the coast (Wood, et al., 2011). This implies a higher aerosol number concentration near the coast and is important in understanding whether the source of this aerosol is anthropogenic or biogenic.

Several studies of aerosol chemical composition on land and in the MBL during and before VOCALS showed that both $\mathrm{SO}_{4}^{2-}$ aerosol, which dominated aerosol mass, and organic aerosols $(\mathrm{OA})$ were of terrestrial origin, with only small contributions from the ocean and the FT. Tomlinson et al. (2007) identified anthropogenic, acidic $\mathrm{SO}_{4}^{2-}$ aerosols during shipboard measurements in the SEP off the coast of Chile and Peru. Chand et al. (2010) identified 4 different types of aerosol sources in Paposo, Chile, several kilometers inland; they included urban/biofuels, soil/smelters, biomass burn, and marine sources. Urban/biofuel sources dominated aerosol mass $(\geq 50 \%)$, with marine being the least important at $\leq 15 \%$. Hawkins et al. (2010) reported shipboard measurements during VOCALS that both $\mathrm{SO}_{4}^{2-}$ and OA were mainly derived from continental outflows. Except for a small marine derived hydroxy-organic class, other aliphatic, carboxyl-organic, and organosulfate classes were all of terrestrial origin. Yang et al. (2011) showed, based on both shipboard and airborne measurements, that MBL sulfur species (primarily $\mathrm{SO}_{4}^{2-}$ ) near the coast were dominated by anthropogenic sources. However, west of $78^{\circ} \mathrm{W}$ continental influence was diminished and the MBL sulfur was dominated by DMS with minor contributions from entrainment of FT air. Shank et al. (2012), focusing on the identification of oceanic OA sources in clean MBL air, found that marine contributions to OA in the SEP were nearly absent because even the very low OA loadings in clean marine air $(\mathrm{CO}<61 \mathrm{ppb})$ were associated with the combustion tracer black carbon. Allen et al. (2011) showed the strong influence of continental emissions on aerosols in the MBL of the SEP east of $80^{\circ} \mathrm{W}$, and long range transport of biomass burn plumes rich in $\mathrm{OA}$ (compared to $\mathrm{SO}_{4}^{2-}$ ) to the FT in the SEP region. $\mathrm{A} \mathrm{SO}_{4}^{2-}$ concentration of $0.3 \mu \mathrm{g} \mathrm{m}^{-3}$ observed in the MBL was considered a background value for the VOCALS region. In this work we report the loadings and chemical composition of fine aerosol particles $\left(D_{\mathrm{p}}<1.5 \mu \mathrm{m}\right)$, measured on board the Department of Energy (DOE) G-1 in the coastal marine atmosphere off northern Chile using both an Aerosol Mass Spectrometer and a Particle-into-Liquid Sampler - Ion Chromatography (PILS-IC) technique, up to $\sim 780 \mathrm{~km}$ offshore $\left(77.8^{\circ} \mathrm{W}\right)$ between $18.4^{\circ} \mathrm{S}$ and $20^{\circ} \mathrm{S}$. Complementing earlier reports, we examine the sources and evolution of aerosol

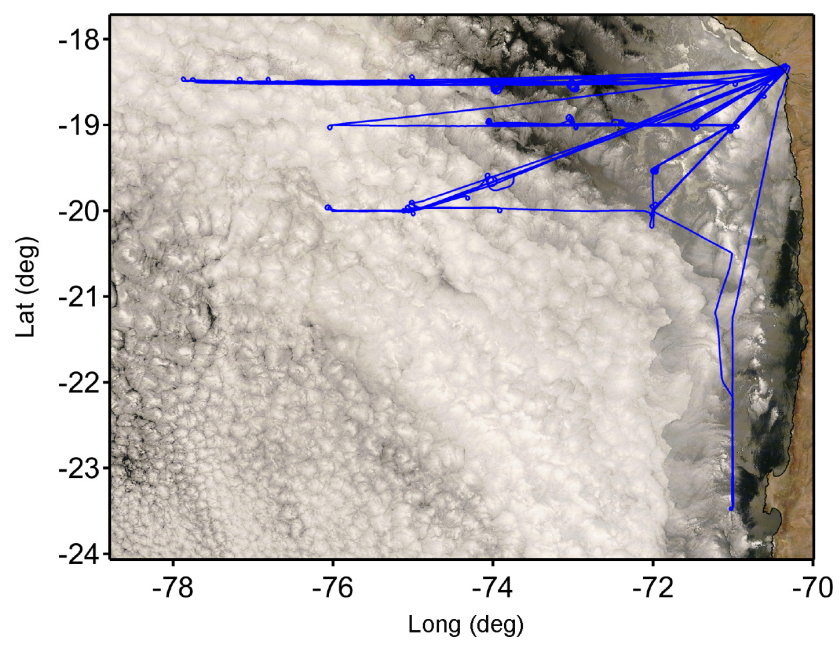

Figure 1. Composite flight tracks of the DOE G-1 during 2008 VOCALS-REx overlaid on a Terra image taken at 16:50, 12 November 2008.

particles to provide additional characterization of the relative importance of land, ocean, and FT contributions to aerosols in the coastal MBL of the SEP.

\section{Experimental section}

The instrumented DOE G-1 aircraft deployed in the VOCALS was supported by the DOE Atmospheric Sciences Program and was among three other aircraft stationed at Arica International Airport, Chile $\left(18^{\circ} 27.44^{\prime} \mathrm{S}, 70^{\circ} 22.37^{\circ} \mathrm{W}\right)$ : NSF C130, UK FAAM Bae-146, and UK NERC Dornier 228 (Wood et al., 2011). The G-1 was equipped with a suite of aerosol and cloud instrumentation for characterizing aerosol chemical composition as well as aerosol and cloud microphysics (Allen et al., 2011). The study took place over the coastal waters off northern Chile in the SEP between 16 October and 15 November 2008. The G-1 conducted 17 research flights mainly between $18^{\circ} \mathrm{S}$ and $20^{\circ} \mathrm{S}$, extending west up to $\sim 78^{\circ} \mathrm{W}$ (Fig. 1), typically between 11:00 and 15:00 local time (LT), each lasting $\sim 4 \mathrm{~h}$. The date and time of the flights are listed in Table 1.

\subsection{Instrumentation}

The G-1 was equipped with instruments for characterizing aerosol particles, cloud droplets, trace gas species, atmospheric state parameters, and winds (Kleinman et al., 2012). The instruments for determining aerosol chemical composition and size distributions are briefly described below; $\mathrm{CO}, \mathrm{O}_{3}$, and $\mathrm{SO}_{2}$ instruments are described elsewhere (Springston et al., 2005). 
Table 1. Date and time of DOE G-1 research flights during VOCALS-REx*.

\begin{tabular}{lccccc}
\hline $\begin{array}{l}\text { Flight } \\
\text { number }\end{array}$ & Date & Take-off (UTC) & Landing & $\begin{array}{c}\text { Westernmost } \\
\left.\text { point (Long }{ }^{\circ} \mathrm{W}\right)\end{array}$ & $\begin{array}{c}\text { Flight } \\
\text { duration }\end{array}$ \\
\hline 1 & 14 Oct 2008 & $15: 52$ & $18: 53$ & 72.4 & $3: 01$ \\
2 & 17 Oct 2008 & $13: 00$ & $16: 50$ & 74.1 & $3: 50$ \\
3 & 18 Oct 2008 & $13: 07$ & $15: 16$ & 72.6 & $2: 09$ \\
4 & 22 Oct 2008 & $16: 32$ & $19: 57$ & 76.1 & $3: 25$ \\
5 & 23 Oct 2008 & $12: 49$ & $16: 35$ & 73.1 & $3: 45$ \\
6 & 25 Oct 2008 & $13: 03$ & $17: 07$ & 76.1 & $4: 04$ \\
7 & 26 Oct 2008 & $13: 01$ & $16: 36$ & 75.1 & $3: 35$ \\
8 & 28 Oct 2008 & $12: 58$ & $17: 16$ & 77.8 & $4: 17$ \\
9 & 29 Oct 2008 & $15: 58$ & $19: 33$ & 72.0 & $3: 35$ \\
10 & 1 Nov 2008 & $12: 57$ & $16: 57$ & 77.2 & $4: 00$ \\
11 & 3 Nov 2008 & $12: 58$ & $16: 51$ & 74.1 & $3: 53$ \\
12 & 4 Nov 2008 & $11: 57$ & $16: 02$ & 72.1 & $4: 05$ \\
13 & 6 Nov 2008 & $11: 57$ & $16: 21$ & 77.9 & $4: 23$ \\
14 & 8 Nov 2008 & $12: 55$ & $16: 31$ & 74.1 & $3: 36$ \\
15 & 10 Nov 2008 & $13: 02$ & $16: 50$ & 75.2 & $3: 47$ \\
16 & 12 Nov 2008 & $13: 20$ & $16: 55$ & 75.3 & $3: 34$ \\
17 & 13 Nov 2008 & $12: 54$ & $16: 42$ & 76.8 & $3: 47$ \\
\hline
\end{tabular}

* 18 Oct 2008 flight was aborted due to research power failure, missing most aerosol data.

\subsubsection{Aerosol Mass Spectrometer}

An Aerodyne Compact Time-of-Flight Aerosol Mass Spectrometer (AMS) was deployed to determine the chemical composition of non-refractory particles in the size range $D_{\mathrm{p}} \sim 70 \mathrm{~nm}$ to $440 \mathrm{~nm}$ (Canagaratna, 2007). In order to maintain a constant transmission efficiency of the particlefocusing lens on the AMS within the altitude range of the G-1 during VOCALS (up to $\sim 3 \mathrm{~km}$ ), a constant pressure chamber maintained at 650 mbar was outfitted upstream of the AMS inlet so that the pressure drop across a pinhole into the AMS was independent of flight altitude. The AMS measurement alternated between the mass spectrometer and the particle time-of-flight (pToF) mode of operation, each complete cycle taking $\sim 22 \mathrm{~s}$ which is the time resolution of the AMS data. The pToF measurements determined the vacuum aerodynamic diameter $\left(D_{\mathrm{VA}}\right)$ of the particles. The chemical species quantified included $\mathrm{NH}_{4}^{+}, \mathrm{SO}_{4}^{2-}, \mathrm{NO}_{3}^{-}, \mathrm{Cl}^{-}$, and Org (total organics), limits of detection (LOD) being $\sim 0.1 \mu \mathrm{g} \mathrm{m}^{-3}$ for $\mathrm{NO}_{3}^{-}, \mathrm{Cl}^{-}$, and $\mathrm{SO}_{4}^{2-}$, and $\sim 0.2 \mu \mathrm{g} \mathrm{m}^{-3}$ for $\mathrm{NH}_{4}^{+}$and Org. The ionization efficiency (IE) was calibrated using $\mathrm{NH}_{4} \mathrm{NO}_{3}$ particles at the end of most flights (Table 2), $\sim 7 \mathrm{~h}$ after the AMS was powered on. A description of the AMS instrument is given by Drewnick et al. (2005).

\subsubsection{Particle-into-Liquid Sampler - Ion Chromatography}

A PILS system (Orsini et al., 2003) was used to determine the bulk chemical composition of particles in the size range $D_{\mathrm{p}} \sim 70 \mathrm{~nm}-\sim 1.5 \mu \mathrm{m}$, the upper size cut limited by the isokinetic inlet outfitted on the G-1 (see below). The species quantified by the PILS included $\mathrm{Na}^{+}, \mathrm{K}^{+}, \mathrm{Ca}^{2+}, \mathrm{Cl}^{-}, \mathrm{NO}_{3}^{-}$, $\mathrm{CH}_{3} \mathrm{SO}_{3}^{-}$(MSA), and $\mathrm{SO}_{4}^{2-}$, with LOD of $\sim 0.3 \mu \mathrm{g} \mathrm{m}^{-3}$ and $\sim 0.1 \mu \mathrm{g} \mathrm{m}^{-3}$ for cations and anions, respectively. Time resolution was $180 \mathrm{~s}$, each sample integrated over a $170 \mathrm{~s}$ period. Although lower in time resolution, the PILS complemented the AMS with detection of MSA, a marker product of DMS oxidation (Yin et al., 1990), and refractory materials such as $\mathrm{NaCl}$ in SSA particles, all potentially important in the MBL. Two glass honeycomb denuders (ChemComb model 3500, Thermo Scientific), one coated with $\mathrm{Na}_{2} \mathrm{CO}_{3}$ and the other with citric acid, were used to remove acidic and basic gases, respectively. The IC's were calibrated for all of the reported ionic species after each flight. In addition to IC analysis, electrical conductivity of the aqueous aerosol samples collected by the PILS was determined at a $10 \mathrm{~s}$ time resolution using a conductivity meter (Consort, model C931, Belgium), with an in-line flow-through conductivity cell inserted between the PILS sampler and the IC's.

\subsubsection{Isokinetic inlet}

The total air flow entering the inlet (sum of that sampled by instruments and the dump flow) was actively controlled using a mass flow controller with real time true air speed, temperature, and pressure as input (Brechtel, 2002). Upon entering the inlet nozzle, the air speed was slowed by a 2-stage diffusion cone wherein the flow was turbulent, resulting in loss of large particles to the wall. At the G-1 cruising speed of $\sim 100 \mathrm{~m} \mathrm{~s}^{-1}$, it was estimated that this isokinetic aerosol inlet has an upper size cut of $D_{\mathrm{p}} \sim 1.5 \mu \mathrm{m}$. During in-cloud passages, cloud droplets shatter in the diffusion cones resulting 
Table 2. AMS ionization efficiency (IE), Air beam counts (AB), IE/ AB, normalization factor, and ratio of total mass to DMA volume.

\begin{tabular}{|c|c|c|c|c|c|}
\hline Date & $\begin{array}{c}\text { Ionization } \\
\text { efficiency }\left(\times 10^{-7}\right)\end{array}$ & $\begin{array}{c}\mathrm{AB} \\
\left(\times 10^{5}\right)\end{array}$ & $\begin{array}{c}\mathrm{IE} / \mathrm{AB} \\
\left(\times 10^{-13}\right)\end{array}$ & $\begin{array}{l}\text { Normalization } \\
\text { factor }\end{array}$ & $\begin{array}{c}\text { Nss_tot } \\
V_{\text {DMA }}\end{array}$ \\
\hline 16 Oct & 2.88 & 3.25 & 8.86 & & \\
\hline 17 Oct & 1.90 & 2.70 & 7.04 & 1.70 & 1.94 \\
\hline 22 Oct & 3.60 & 6.90 & 5.22 & 1.45 & 1.10 \\
\hline 23 Oct & 3.43 & 6.73 & 5.10 & 0.97 & 1.17 \\
\hline 25 Oct & 2.83 & 4.60 & 6.15 & 1.41 & 1.32 \\
\hline 26 Oct & 1.93 & 3.10 & 6.23 & 1.28 & 1.29 \\
\hline 28 Oct & 2.10 & 3.70 & 5.76 & 1.54 & 0.96 \\
\hline 29 Oct & & & & 1.92 & 1.06 \\
\hline $1 \mathrm{Nov}$ & 1.63 & 2.15 & 7.60 & 0.87 & 0.93 \\
\hline $3 \mathrm{Nov}$ & & & & 1.20 & 1.54 \\
\hline $4 \mathrm{Nov}$ & 2.82 & 5.56 & 5.07 & 1.68 & 1.08 \\
\hline $6 \mathrm{Nov}$ & & & & 2.21 & 0.98 \\
\hline $8 \mathrm{Nov}$ & & & & 1.23 & 0.89 \\
\hline 9 Nov* & 3.82 & 6.35 & 6.02 & & \\
\hline $10 \mathrm{Nov}$ & & & & 1.14 & 0.87 \\
\hline $12 \mathrm{Nov}$ & 3.85 & 6.21 & 6.21 & 1.16 & 1.2 \\
\hline $13 \mathrm{Nov}$ & & & & 1.40 & \\
\hline
\end{tabular}

* Ground study.

in large number of particles (mode $D_{\mathrm{p}} \sim 50 \mathrm{~nm}$ ) that are too small for the AMS and PILS to sample.

\subsubsection{Differential mobility analyzer (DMA)}

A DMA (Wang et al., 2003) which draws air from the isokinetic inlet sample manifold was used to determine size distributions of aerosol particles between $D_{\mathrm{p}} \sim 15 \mathrm{~nm}$ and $440 \mathrm{~nm}$. The RH of the sample air was reduced to $\sim 15 \%$ using a Nafion dryer upstream of the DMA. A complete size distribution was determined every $60 \mathrm{~s}$ representing an average of two $30 \mathrm{~s}$ scans.

\subsection{Sampling strategy}

The primary objective of the G-1 mission was to characterize the chemical and microphysical properties of aerosol particles and their effects on cloud microphysics. The strategy was to sample below-, in-, and above-cloud so that relations and interactions between aerosols and clouds could be investigated. Because of its limited range $(4 \mathrm{~h}, \sim 1400 \mathrm{~km})$, the G-1 typically took a straight east-west transect attempting to reach the furthest possible distance from the coast so that a contrast in cloud aerosol relationships could be characterized between the pristine marine environment offshore and polluted MBL near the coast. Because the clouds tended to dissipate westward from land starting around midday, the G-1 typically conducted cloud studies during outbound legs when cloud coverage was still extensive, and MBL sampling during the inbound legs when the near-shore clouds had often dissipated. On the inbound leg, the G-1 typically flew at a constant low altitude of $100 \mathrm{~m}$.

\section{Results}

\subsection{Data coverage}

A composite flight track of all 17 G-1 research flights during VOCALS is shown in Fig. 1. Except for the flight of 29 October 2008, all of the G-1 flights took place between $18.4^{\circ} \mathrm{S}$ and $20^{\circ} \mathrm{S}$ and were predominantly east-west in order to characterize land-sea gradients in aerosol and cloud properties in below-cloud (BC, RH $>50 \%$ and $\mathrm{LWC}<0.01 \mathrm{~g} \mathrm{~m}^{-3}$ ), in-cloud, and above-cloud (AC, $\mathrm{RH}<45 \%$ and $\mathrm{LWC}<0.01 \mathrm{~g} \mathrm{~m}^{-3}$ ) segments.

\subsection{Merging AMS and PILS data}

The PILS and the AMS both measured aerosol $\mathrm{SO}_{4}^{2-}, \mathrm{NH}_{4}^{+}$, and $\mathrm{NO}_{3}^{-}$, but only the PILS measured $\mathrm{Na}^{+}, \mathrm{Cl}^{-}$, and MSA, and only the AMS measured Org. To examine the relationship between all of the species on a common basis, the AMS data are normalized to the PILS data using the slope of the least-squares fit of the correlation plot of non-sea-salt $\mathrm{SO}_{4}^{2-}$ (nss- $\mathrm{SO}_{4}^{2-}$ ) concentrations determined by these two methods, one for each flight (Table 2), assuming that nss- $\mathrm{SO}_{4}^{2-}$ was present only in particles of $D_{\mathrm{p}}<440 \mathrm{~nm}$. Sea-salt $\mathrm{SO}_{4}^{2-}$ (ss- $\mathrm{SO}_{4}^{2-}$ ) was calculated using the observed $\left[\mathrm{Na}^{+}\right]$and the sea-water $\left[\mathrm{SO}_{4}^{2-}\right] /\left[\mathrm{Na}^{+}\right]$ratio. This normalization adjusts the concentrations of all the species measured by the AMS by a constant factor, but not their trends and relative concentrations. Merging the AMS and PILS data in this way provides a uniform data set which can be used for comparison to other aerosol measurements (see below). This merging procedure 
does not imply that the PILS data are more accurate than the AMS data. With that we note that the AMS IE calibration exhibited a fairly large variability over the course of the mission (Table 2). Although the core AMS instrument response (or sensitivity) characterized by the ratio of IE to air beam signal strength (IE/AB) was comparatively more stable, the IE / AB ratio did not show a correlation with the normalization factor (Table 2). We suspect that the variability in the AMS calibration was due mainly to an insufficient warm-up time of the AMS (the total time from power on and pump down until calibration was only $\sim 7 \mathrm{~h}$ ).

\subsection{Comparison of concentrations of aerosol mass with aerosol volume}

To examine the quantitativeness of the aerosol mass concentration measurements, we examine the ratio of the total aerosol mass concentrations computed from a combination of the AMS and PILS concentration measurements, to the total aerosol volume concentrations calculated from the size distributions determined by the DMA. This ratio should approximate the particle density if all of the aerosol species are accounted for by the combination of the PILS and AMS measurements. Because the PILS detected particles larger than the AMS (i.e, between $D_{\mathrm{p}} \sim 0.4 \mu \mathrm{m}$ and $\sim 1.5 \mu \mathrm{m}$ ), which are presumably due mainly to SSA, we also examine the nss fraction of the PILS mass concentrations (by excluding $\mathrm{Na}^{+}$, $\mathrm{Cl}^{-}, \mathrm{Mg}^{2+}, \mathrm{ss}_{-} \mathrm{SO}_{4}^{2-}$, and $\mathrm{NO}_{3}^{-}$) to the DMA volume.

The slope of the plot of the aerosol mass concentration vs. aerosol volume for the flight of 28 October 2008 (Fig. 2) is near unity implying a particle density that is significantly lower than the $\sim 1.7 \mathrm{~g} \mathrm{~cm}^{-3}$ expected for aerosol particles predominately composed of sulfate. Two possible reasons for this are: (1) the presence of components undetected by the PILS, including non-activated particles and unquantified ionic species that contribute to the aerosol volume; (2) water associated with un-neutralized $\mathrm{H}_{2} \mathrm{SO}_{4}$ at the DMA's operating $\mathrm{RH}$ of $15 \pm 2 \%$ which increases the aerosol volume over that calculated considering only dry components. There is no good way to evaluate the first reason with the available data. As for the second reason, Kleinman et al. (2012) showed that a solution containing $\mathrm{NH}_{4} \mathrm{HSO}_{4}$ and $\mathrm{H}_{2} \mathrm{SO}_{4}$ mixed with $10 \%$ insoluble organics similar to the aerosol composition observed during VOCALS is calculated to exhibit a volume growth factor of 1.3 at $\mathrm{RH}=15 \%$. With this growth factor taken into account (bringing the slope to $\sim 1.4$ ), there is $\mathrm{a} \sim 25 \%$ underestimation of aerosol mass compared to the DMA volume, part of which could be caused by unidentified constituents.
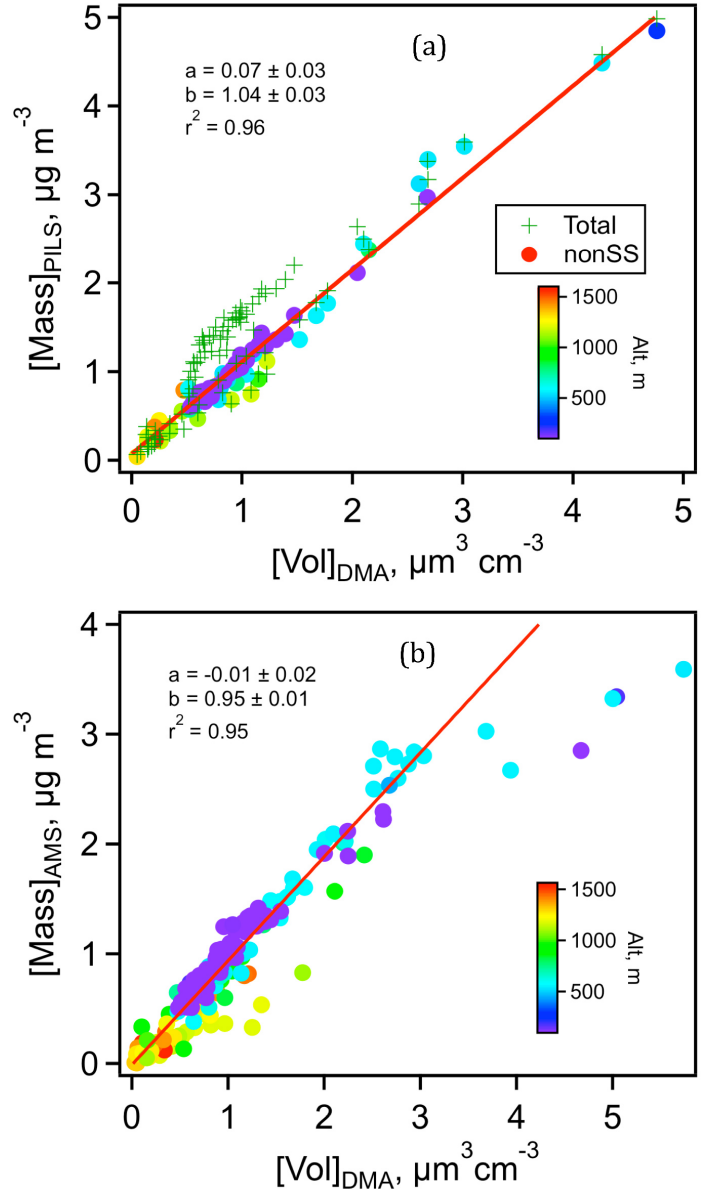

Figure 2. Comparison of aerosol mass concentrations determined using the PILS and the AMS with the aerosol volume concentrations calculated from DMA size distributions: (a) mass concentrations of ionic species from PILS and Org from the AMS with (crosses) and without (solid circles) SSA components: (b) mass concentrations determined using the AMS, normalized to the PILS using nss- $\mathrm{SO}_{4}^{2-}$. Solid lines are least squares best fits.

\subsection{Aerosol chemical composition}

\subsubsection{Synopsis}

The AMS measured detectable amounts of $\mathrm{SO}_{4}^{2-}, \mathrm{NH}_{4}^{+}$, and Org at nearly all locations, but not $\mathrm{Cl}^{-}$and $\mathrm{NO}_{3}^{-}$which were below their LOD's of $\sim 0.05 \mu \mathrm{g} \mathrm{m}^{-3}$ throughout the study. Neither $\mathrm{NaCl}$ or $\mathrm{NaNO}_{3}$ in SSA particles were detected by the AMS because they are refractory under our operating conditions. The PILS measured $\mathrm{Na}^{+}, \mathrm{Cl}^{-}, \mathrm{NO}_{3}^{-}$, as well as $\mathrm{NH}_{4}^{+}$and $\mathrm{SO}_{4}^{2-}$, MSA, $\mathrm{K}^{+}$and $\mathrm{Ca}^{2+}$. MSA was found in only a few samples and $\mathrm{K}^{+}$and $\mathrm{Ca}^{2+}$ were always below their LOD's of $\sim 0.15 \mu \mathrm{g} \mathrm{m}^{-3}$. Chemical composition of MBL aerosol particles was dominated by $\mathrm{SO}_{4}^{2-}$, which on average accounted for $\sim 50 \%$ of the measured total aerosol mass, followed by $\mathrm{Na}^{+}, \mathrm{Cl}^{-}, \mathrm{Org}, \mathrm{NO}_{3}^{-}$, and $\mathrm{NH}_{4}^{+}$, each with 


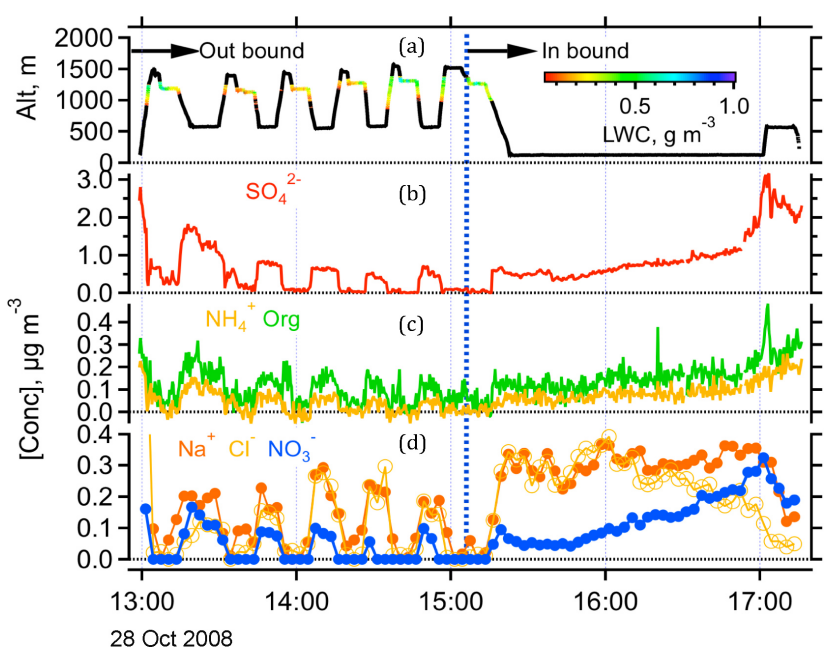

Figure 3. Time plots of altitude and aerosol chemical concentrations measured on the 28 Oct 2008 flight. The aircraft altitude plot is color-coded to the liquid water content of clouds encountered during the out-bound leg (a); the blue dotted vertical line marks the time when the G-1 turned around and headed back to Arica.

a contribution of $<15 \%$. A strong land-to-sea gradient was seen in $\mathrm{NH}_{4}^{+}, \mathrm{SO}_{4}^{2-}$, Org, and $\mathrm{NO}_{3}^{-}$, while $\mathrm{Na}^{+}$and $\mathrm{Cl}^{-}$were fairly uniformly distributed longitudinally. Aerosol composition and the longitudinal gradient in aerosol loading were fairly consistent during the month long study, and are well represented by the data collected on the 28 October 2008 flight which is described below.

\subsubsection{October 2008 Flight}

The G-1 flew west along $18.5^{\circ} \mathrm{S}$ after taking off at 09:58 LT and repeated a below-, in-, and above-cloud staircase pattern until reaching the westernmost point $\left(77.8^{\circ} \mathrm{W}\right.$, Fig. 3a). The $\mathrm{BC}$ transects during the outbound segment were at $\sim 600 \mathrm{~m}$. After turning around and returning to Arica, the G-1 sampled MBL air at an altitude of $100 \mathrm{~m}$ all of the way to the coast. The $\mathrm{BC} \mathrm{NH}+, \mathrm{SO}_{4}^{2-}$, Org, and $\mathrm{NO}_{3}^{-}$concentrations which showed a clear land-to-sea gradient were nearly invariant at a given location during the 4-hour flight period: the values at $600 \mathrm{~m}$ (outbound) and at $100 \mathrm{~m}$ (inbound) were identical to within $10 \%$ (Fig. 3b and c). In contrast, concentrations of $\mathrm{Na}^{+}$and $\mathrm{Cl}^{-}$, representing SSA particles, were rather constant longitudinally; the $\mathrm{Cl}^{-}$deficit was more pronounced near the coast (Fig. 3d). Concentrations of all aerosol species dropped significantly during in-cloud segments (colored sections of the altitude trace in Fig. 3a) because aerosol particles incorporated into cloud droplets are not detected by either the AMS or the PILS. Much lower concentrations of most of the species were observed in $\mathrm{AC}$ than in $\mathrm{BC}$, reflecting generally cleaner conditions of the FT and because fewer aerosol surface sources directly supply this layer.

\subsection{Ensemble aerosol chemical composition}

All of the clear air aerosol composition data is examined in this section to allow characterization of horizontal and vertical distribution patterns. The data are segregated into the $\mathrm{BC}$ and AC regions. Some of the samples identified as AC, in particular those near the coast, had no clouds below them, but are assigned as $\mathrm{AC}$ based on potential temperature data. Some AC data were within the inversion, devoid of clouds but remained moist.

\subsubsection{Composite longitudinal distributions}

$\mathrm{BC}$ concentrations of $\mathrm{SO}_{4}^{2-}, \mathrm{NH}_{4}^{+}$, and Org determined using the AMS, and $\mathrm{Na}^{+}$and $\mathrm{NO}_{3}^{-}$determined using the PILS are plotted as a function of longitude in Fig. 4. Overlaid on the data points are box plots of one-degree binned data in longitude for $\mathrm{SO}_{4}^{2-}, \mathrm{NH}_{4}^{+}$, and $\mathrm{Org}$, and two-degree binned data (separated by $-72,-74$, and $-76^{\circ} \mathrm{W}$ ) for $\mathrm{Na}^{+}$and $\mathrm{NO}_{3}^{-}$. AC concentrations of these five species are plotted analogously, but with RH shown to identify recent contact with the surface (Fig. 5). All of the box plots in this work show the median and the inner quartiles by the center, bottom, and top cross bars of the rectangular boxes, and the $5 \%$ and $95 \%$ ranges by the whiskers. To present data patterns in a continuous fashion, to facilitate comparisons, we also include Locally Weighted Scatter Smoothing (LOWESS) (Cleveland, 1979) lines as proxies for median values. The good agreement between these two approaches can be seen in Figs. 5 and 6 where the LOWESS lines are overlaid on the box plots.

The LOWESS fits for $\mathrm{BC}$ concentrations of $\mathrm{SO}_{4}^{2-}, \mathrm{NH}_{4}^{+}$, Org, and $\mathrm{NO}_{3}^{-}$(Fig. 4) exhibit pronounced longitudinal gradients with concentrations lower offshore than near the coast. In contrast, the median of SSA represented by $\mathrm{Na}^{+}$, exhibits a rather uniform longitudinal distribution, increasing slightly offshore. These gradients are consistent with a continental source for $\mathrm{SO}_{4}^{2-}, \mathrm{NH}_{4}^{+}, \mathrm{Org}$, and $\mathrm{NO}_{3}^{-}$. The median $\mathrm{AC}$ concentrations of $\mathrm{SO}_{4}^{2-}$ and $\mathrm{NH}_{4}^{+}$(Fig. 5) also exhibited a landto-sea gradient, showing the influence of nearby terrestrial sources, likely in Chile and Peru (Allen et al., 2011). Higher $\mathrm{AC}$ concentrations of $\mathrm{SO}_{4}^{2-}, \mathrm{NH}_{4}^{+}$, as well as Org, near the coast (east of $\sim 73^{\circ} \mathrm{W}$ ) were associated with moist air (RH up to $\sim 50 \%$, Fig. 5) that was likely transported vertically from the surface by diurnal pumping in the steep coastal terrain followed by advection to the Pacific (Bretherton et al., 2010; Allen et al., 2011; Kleinman et al., 2012). Unlike $\mathrm{SO}_{4}^{2-}$ and $\mathrm{NH}_{4}^{+}$, the median AC Org concentration exhibited almost no longitudinal dependence, with only a slight dip at the westernmost reach of the G-1, indicating that long-range transport of air masses enriched in Org but depleted in $\mathrm{SO}_{4}^{2-}$ and $\mathrm{NH}_{4}^{+}$had impacted the FT west of $73^{\circ} \mathrm{W}$. We note that while the driest $\mathrm{AC}$ air typically contained the lowest $\mathrm{SO}_{4}^{2-}$ and $\mathrm{NH}_{4}^{+}$(in red, Fig. 5), the AC Org was still appreciable in the driest air derived from long-range transport appearing 

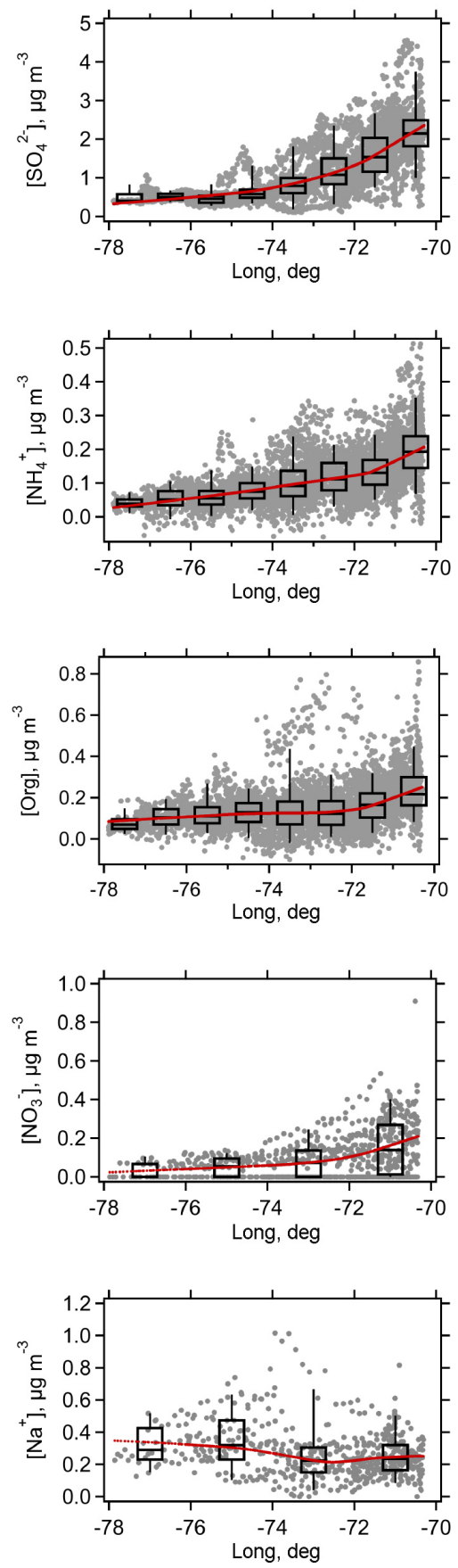

Figure 4. Composite longitudinal dependence of below-cloud (BC) aerosol concentrations determined on the G-1 for the entire VOCALS mission. Box plots (black) and LOWESS smooth (red) are overlaid on individual data points (grey).

between $\sim 74^{\circ} \mathrm{W}$ and $\sim 76^{\circ} \mathrm{W}$. This observation suggests that OA, presumably associated with biomass burns (Allen et al., 2011), was not completely removed by wet processes which were inferred from low [Org] / [CO] ratios (Kleinman et al., 2012). AC concentrations of $\mathrm{Na}^{+}$(not shown) were much smaller than BC concentrations (Fig. 5), and exhib-
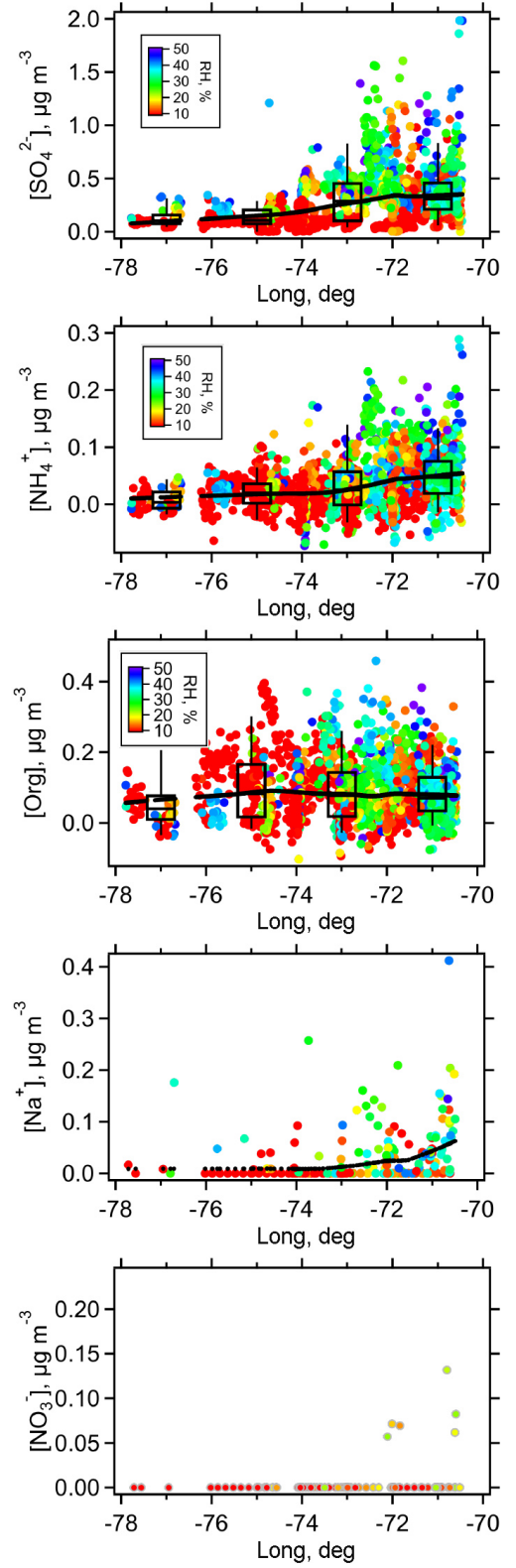

Figure 5. Composite longitudinal distributions of aerosol concentrations of $\mathrm{AC} \mathrm{SO}_{4}^{2-}, \mathrm{NH}_{4}^{+}$, Org, $\mathrm{Na}^{+}$, and $\mathrm{NO}_{3}^{-}$measured on the G-1 for the entire mission. Data are color coded to RH; solid black line represents LOWESS smooth. Box plots are for two-degree binned data.

ited a small gradient near the coast. Only a few AC samples contained measurable $\mathrm{NO}_{3}^{-}$. Aerosol MSA, a product of DMS from $\mathrm{OH}$-addition reaction favored at lower temperatures (e.g., Yin et al., 1990), rarely exceeded its LOD; only 50 out of the 1150 PILS samples had concentrations greater than its LOD of $0.05 \mu \mathrm{g} \mathrm{m}^{-3}$; of which only 15 were greater than $0.1 \mu \mathrm{g} \mathrm{m}^{-3}$. All 50 samples were close to the coast, i.e., east of $72.5^{\circ} \mathrm{W}$. 


\subsubsection{Composite vertical distributions}

The altitude dependence of $\mathrm{SO}_{4}^{2-}, \mathrm{NH}_{4}^{+}$, and Org determined by the AMS are shown in Fig. 6 . We note that the $\mathrm{BC}$ and $\mathrm{AC}$ data overlapped between $\sim 800 \mathrm{~m}$ and $\sim 1500 \mathrm{~m}$, reflecting the variability in local MBL height and cloud thickness, as well as a systematic increase of MBL height offshore (Rahn and Garreaud, 2010). The plots show that median $\mathrm{BC} \mathrm{SO}_{4}^{2-}$ was significantly higher than that of $\mathrm{AC}$, and that a clear discontinuity exists between the MBL and FT. This BC-AC difference is less distinct for $\mathrm{NH}_{4}^{+}$and nearly absent for Org (Fig. 6). The $\mathrm{BC} \mathrm{SO}_{4}^{2-}$ determined by the PILS exhibited a vertical pattern that agreed well with the $\mathrm{AMS} \mathrm{SO}_{4}^{2-}$ (Fig. 6). The median $\mathrm{BC}$ concentration profiles for $\mathrm{SO}_{4}^{2-}, \mathrm{NH}_{4}^{+}$, and Org also show apparent maxima at altitudes of $\sim 450 \mathrm{~m}$, $\sim 250 \mathrm{~m}$, and $\sim 500 \mathrm{~m}$, respectively (Fig. 6). Finally, we note that while the $\mathrm{BC} \mathrm{Na}^{+}$exhibited a small vertical gradient, decreasing with altitude, $\mathrm{BC} \mathrm{NO}_{3}^{-}$which was found to reside on SSA particles showed a vertical profile similar to those of $\mathrm{SO}_{4}^{2-}$ and $\mathrm{Org}$, and a maximum at $\sim 350 \mathrm{~m}$ (not shown). These composite distribution patterns are influenced by sampling biases with respect to time and location, and do not represent true vertical variability of a quantity at a given location and time like a sounding, but nonetheless have some value for illustrating the differences between the vertical distributions of the simultaneously measured species.

\section{Discussion}

\subsection{Aerosol acidity}

The aerosol composition determined on the G-1 was dominated by $\mathrm{SO}_{4}^{2-}$, with $\mathrm{NH}_{4}^{+}$and $\mathrm{Org}$ each accounting for no more than $15 \%$ of the total mass. The median values of $\mathrm{BC}$ $\mathrm{NH}_{4}^{+}$to $\mathrm{SO}_{4}^{2-}$ equivalents ratios as a function of longitude varied between 0.25 and 0.3 , indicating the $\mathrm{SO}_{4}^{2-}$ aerosols were strongly acidic. More than $90 \%$ of the samples were acidic exhibiting $\mathrm{NH}_{4}^{+}$to $\mathrm{SO}_{4}^{2-}$ equivalents ratios $\leq 0.8$. To confirm this inferred acidity, we examine the charge balance of the ionic species, using data of 28 October 2008 as an example. A plot of the total positive ion equivalents against the total negative equivalents (ionic equivalents $=\Sigma z_{i} c_{i}$, where $z_{i}$ is the charge and $c_{i}$ is the concentration) for each of the PILS samples shows an overwhelming cation deficit as all the data points lie below the $1: 1$ line of charge neutrality (Fig. 7). However, when the electrical charges associated with the un-neutralized $\mathrm{H}_{2} \mathrm{SO}_{4}$ were taken into account, the slope of the plot was very close to unity. Below, we further use the conductivity of the PILS samples to provide evidence that $\mathrm{H}_{3} \mathrm{O}^{+}$was the plausible missing cation.

The time series of the measured conductivity of PILS samples on 28 October 2008 is shown along with the conductivity calculated from the ions measured by the PILS (in red and green traces, respectively, Fig. 8).
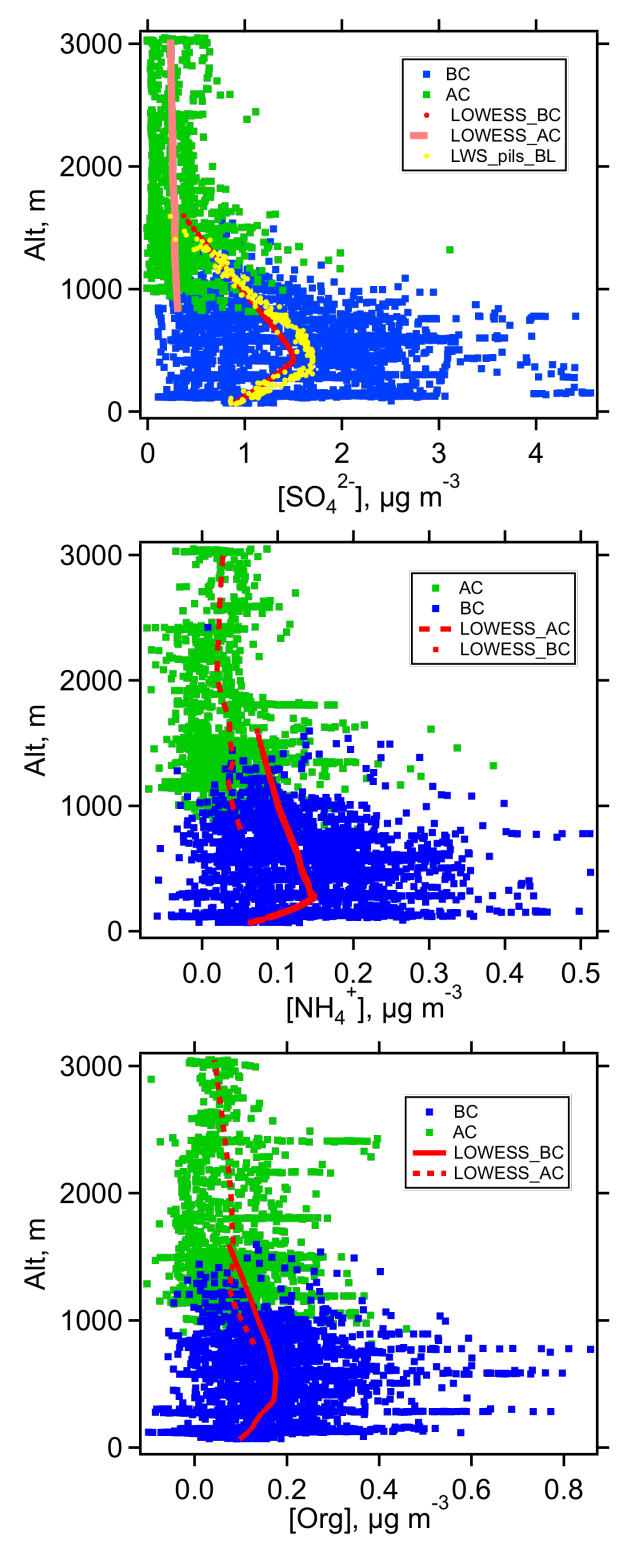

Figure 6. Composite vertical distributions of the concentrations of $\mathrm{SO}_{4}^{2-}, \mathrm{NH}_{4}^{+}$, and Org for the entire G-1 mission. Continuous lines (dashed as well as solid) represent LOWESS smooth.

The calculated conductivity includes $\mathrm{H}^{+}$and $\mathrm{HCO}_{3}^{-}$in equilibrium with atmospheric $\mathrm{CO}_{2}(380 \mathrm{ppm}$, Henry's Law solubility $\mathrm{H}_{\mathrm{CO}_{2}}=0.04 \mathrm{M} \mathrm{atm}^{-1}$, dissociation constant $K_{\mathrm{a}}=4.25 \times 10^{-7} \mathrm{M}$, both at $25^{\circ} \mathrm{C}$ ) assuming the $\mathrm{pH}$ of the liquid sample was governed by $\mathrm{CO}_{2}$. The calculated conductivity is significantly smaller than the conductivity observed, except during the in-cloud and above-cloud segments where the aerosol loading was greatly reduced. We point out that a positive offset of $0.15 \mu \mathrm{S} \mathrm{cm}^{-1}$ was added to the calculated conductivity so that the lowest conductivity matches the conductivity observed in the FT (15:00-15:10, Fig. 8) where a minimum aerosol loading is expected. With the assumption 


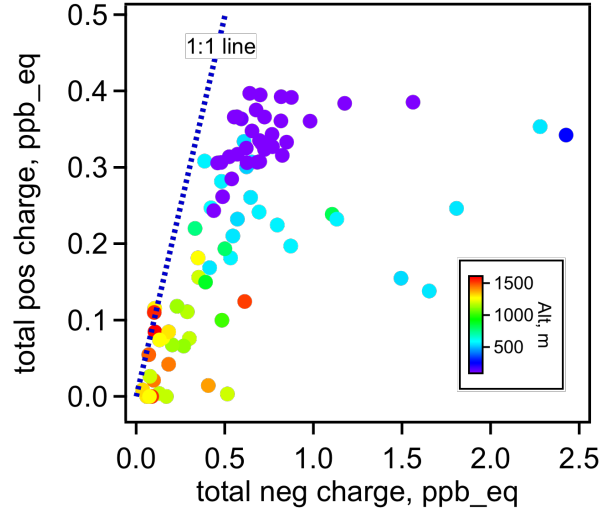

Figure 7. Charge balance of aerosol components determined using the PILS-IC on 28 October 2008. The units are in parts-per-billion (ppb) multiplied by charge equivalents. Positive ions were dominated by $\mathrm{Na}^{+}$and $\mathrm{NH}_{4}^{+}$; negative by $\mathrm{Cl}^{-}, \mathrm{NO}_{3}^{-}$, and $\mathrm{SO}_{4}^{2-}$.

that $\mathrm{H}_{3} \mathrm{O}^{+}$is the missing cation, the recalculated conductivity (blue trace, Fig. 8) shows a much-improved agreement with the conductivity observed, with $>80 \%$ of the differences accounted for. Because no other cations can make up this difference due to their much smaller equivalent conductances compared to that of the $\mathrm{H}_{3} \mathrm{O}^{+}$, we conclude that $\mathrm{H}_{3} \mathrm{O}^{+}$was indeed the missing cation. The conclusion that the $\mathrm{SO}_{4}^{2-}$ aerosols were strongly acidic agrees with Tomlinson et al. (2007) based on aerosol volatility properties. We note that the calculated conductance was lower than that observed in the MBL between $\sim 73^{\circ} \mathrm{W}$ and $\sim 77^{\circ} \mathrm{W}$ with a magnitude upward of $0.1 \mu \mathrm{S} \mathrm{cm}^{-1}$. This discrepancy suggests the presence of other ionic species that were collected but not identified by the IC. Similarly, the calculated conductivity was lower than that observed during the first three AC transects near the coast but not during the last three offshore, suggesting the presence of appreciable aerosol loading in the nearshore AC layer whose ionic components were not measured by the PILS (e.g., dust and OA).

\subsection{Sea-salt aerosol characterization}

While the main production mechanism of SSA particles is bubble bursting followed by wave breaking which is strongly wind speed (WS) dependent, the SSA loadings in the MBL are governed by a number of factors, including production, entrainment, transport, mixing height, as well as removal by precipitation and dry deposition (Lewis and Schwartz, 2004). The observed SSA concentrations during VOCALS represent an ideal data set for comparison to parameterizations of the relationship between SSA loading and WS because of the expansive and uniform wind field characterizing the SEP (Rahn and Garreaud, 2010).

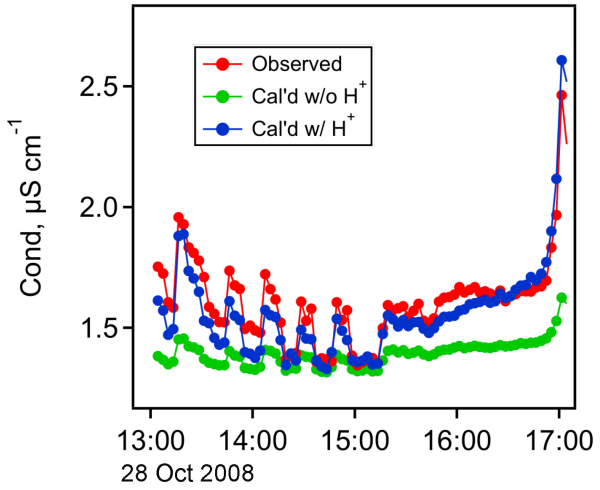

Figure 8. Comparison of the observed and calculated conductivities of the liquefied aerosol samples collected by the PILS on the 28 Oct 2008 flight.

\subsubsection{Wind speed dependence of SSA loading}

The MBL wind direction (WD) measured on the G-1 exhibited a bimodal distribution with peaks at $\sim 160^{\circ}$ and $\sim 190^{\circ}$ (directions the wind originated from) east of $71.5^{\circ} \mathrm{W}$, with only a single mode at $\sim 160^{\circ}$ west of $71.5^{\circ} \mathrm{W}$ (Fig. 9a). This wind pattern is similar to that found by Rahn and Garreaud (2010). The MBL WS measured on the G-1 is plotted as a function of longitude in Fig. 9b; the median WS increased with distance offshore from $\sim 3.5 \mathrm{~m} \mathrm{~s}^{-1}$ to $8 \mathrm{~m} \mathrm{~s}^{-1}$ (Fig. 9b).

The LOWESS fit of the WS dependence of $\mathrm{BC}[\mathrm{NaCl}]$ (Fig. 10) exhibits a positive correlation for $\mathrm{WS} \geq 5 \mathrm{~m} \mathrm{~s}^{-1}$ consistent with the notion of a threshold WS for wind stress induced SSA production. This observed WS dependence of $[\mathrm{NaCl}]$ is nearly parallel to that recommended by Lewis and Schwartz (2004, Fig. 17 therein), scaled to reflect $\mathrm{NaCl}$ only (blue line, Fig. 10). Since the isokinetic inlet on the G-1 is expected to effect an upper size cut of $D_{\mathrm{p}} \sim 1.5 \mu \mathrm{m}$, we evaluate the $\mathrm{NaCl}$ loadings according to these two size limits based on the canonical size distributions at WS's of 7 and $9 \mathrm{~m} \mathrm{~s}^{-1}$ (Lewis and Schwartz, 2004, Table 14) for comparison (Fig. 10). The observed median values are flanked by these calculated values consistent with the estimated inlet size cut of $\sim 1.5 \mu \mathrm{m}$ (Brechtel, 2002). The particle size used in the calculations were for SSA in equilibrium at $\mathrm{RH}=80 \%$, and the observed median BC RH values increased from $\sim 70 \%$ near the sea surface to $\sim 90 \%$ just below the cloud.

The total SSA number concentration, $N_{\mathrm{SSA}}$, estimated from the canonical size distribution are $3.5 \mathrm{~cm}^{-3}$ and $6.0 \mathrm{~cm}^{-3}$ at WS $=7 \mathrm{~m} \mathrm{~s}^{-1}$ and $9 \mathrm{~m} \mathrm{~s}^{-1}$, respectively, which were greater than the total $N_{\mathrm{SSA}}$ under $D_{\mathrm{p}}=2 \mu \mathrm{m}$ by only $\sim 5 \%$. Consequently, in terms of number concentration, the SSA represented only a tiny fraction of the total accumulation mode particles even over the cleanest region the G1 surveyed which was $\sim 150 \mathrm{~cm}^{-3}$. This estimate is much lower than Blot et al. (2013) who found that SSAs active as 

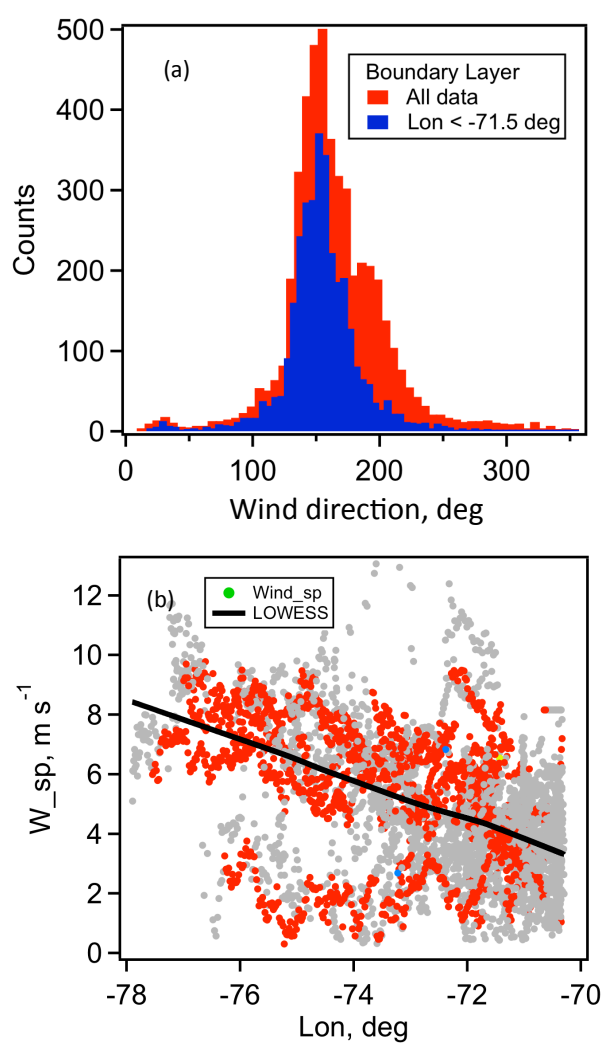

Figure 9. (a) Histogram of MBL wind directions measured on the G-1 during VOCALS showing a consistent southerly near the coast that shifted slightly towards the NNW $\left(155^{\circ}\right)$ offshore. (b) Wind speed dependence on longitude where the black line represents the LOWESS smooth, and the data points in red correspond to altitudes less than $150 \mathrm{~m}$.

cloud condensation nuclei at $0.25 \%$ supersaturation varied between 17 and $36 \mathrm{~cm}^{-3}$.

There was a small negative WS dependence of $[\mathrm{NaCl}]$ for WS $<5 \mathrm{~m} \mathrm{~s}^{-1}$ (Fig. 10). Since bubble bursting associated with wave breaking is no longer the main source of SSA in this WS range, the elevated SSA levels observed are either transported from upwind or produced by a different mechanism. Recognizing that the near-shore WS was the lowest (Fig. 9b), we surmise that wave breaking in the coastal surf zone was an important source of SSA, which diminished with distance from the coast and manifested in the apparent negative WS dependence.

\subsubsection{Uptake of $\mathrm{HNO}_{3}, \mathrm{H}_{2} \mathrm{SO}_{4}$ and $\mathrm{CH}_{3} \mathrm{SO}_{3} \mathrm{H}$ by SSA particles}

SSA particles often exhibit $\mathrm{Cl}^{-}$deficit caused by strong acids, $\mathrm{H}_{2} \mathrm{SO}_{4}$ and/or $\mathrm{HNO}_{3}$, which drive off the volatile $\mathrm{HCl}$, leaving behind the respective refractory $\mathrm{Na}$ salts (e.g., Kawakami et al., 2008). The $\mathrm{Cl}^{-}$deficit observed during VOCALS was substantial, with a mission-average $\mathrm{Cl}^{-}$to $\mathrm{Na}^{+}$molar ratio of 0.77 , representing a loss of $\sim 1 / 3{\text { of } \mathrm{Cl}^{-}}^{-}$

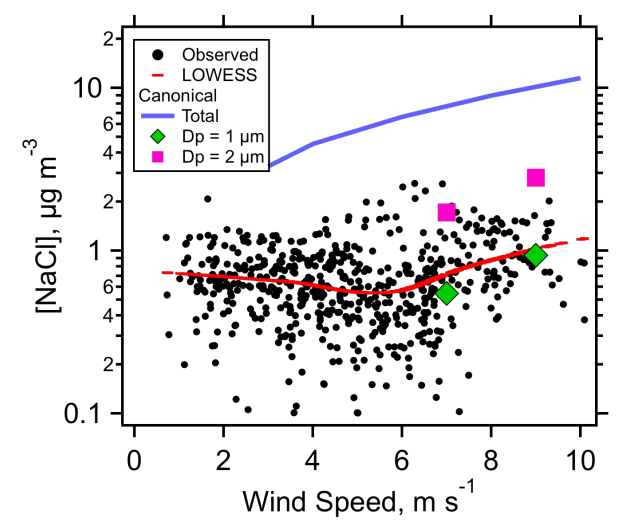

Figure 10. Wind speed dependence of MBL SSA mass concentration (as $\mathrm{NaCl}$ ) determined on the G-1 during VOCALS. The solid red line represents the LOWESS smooth of the observed $\mathrm{NaCl}$ concentrations. The solid blue line represents empirical relationship between the total mass of SSA (scaled to $\mathrm{NaCl}$ ) and the wind velocity at $10 \mathrm{~m}$ above sea surface (Fig. 17 in Lewis and Schwartz, 2004). The two sets of symbols in green and magenta represent the calculated concentrations with a $1 \mu \mathrm{m}$ and $2 \mu \mathrm{m}$ upper size limit, respectively.

(Fig. 11). Since $\mathrm{NO}_{3}^{-}$was detected by the PILS, which detects soluble $\mathrm{NO}_{3}^{-}$, and the AMS which detects only nonrefractory species reported no $\mathrm{NO}_{3}^{-}$(LOD of $\sim 0.1 \mu \mathrm{g} \mathrm{m}^{-3}$ ) throughout the entire mission, $\mathrm{HNO}_{3}$ is identified as the primary acidifying reagent contributing to the observed $\mathrm{Cl}^{-}$ deficit. These observations suggest that SSA and sulfate aerosol remain mostly externally mixed in the MBL, consistent with their different production mechanisms (i.e., sea salt is mechanically produced, whereas sulfate is produced by a combination of gas and aqueous phase processes; while aqueous phase production will occur in cloud droplets formed on SSA aerosol particles, the number of SSA particles is very small). In this regard, we note that MSA, if present, would behave similarly to $\mathrm{HNO}_{3}$, i.e., retained as a Na salt in SSA but not in the acidic $\mathrm{SO}_{4}^{2-}$ aerosols and therefore not detected by the AMS.

The observed aerosol $\mathrm{NO}_{3}^{-}$concentrations only explained a portion of the $\mathrm{Cl}^{-}$deficit: with $\mathrm{NO}_{3}^{-}$taken into account, a $\sim 25 \% \mathrm{Cl}^{-}$deficit remains, presumably due to $\mathrm{H}_{2} \mathrm{SO}_{4}$. Uptake of gaseous $\mathrm{H}_{2} \mathrm{SO}_{4}$, coagulation with sulfate aerosols, and in-cloud oxidation of $\mathrm{SO}_{2}$ can in principle achieve incorporation of $\mathrm{H}_{2} \mathrm{SO}_{4}$ into SSA. The rate of collision coalescence of SSA with sulfate aerosols is too slow to be important for acidifying SSA. The characteristic time constant for removing $\mathrm{SO}_{4}^{2-}$ particles at an SSA particle concentration of $\sim 4 \mathrm{~cm}^{-3}$ and a coalescence coefficient of $\mathrm{K} \leq 5 \times 10^{-9} \mathrm{~cm}^{3} \mathrm{~s}^{-1}$ is estimated to be $\geq 500$ days. Although the in-cloud aqueous oxidation process can be important considering its fast reaction kinetics and the prevalence of cloud in the study region, a quantitative evaluation is unfortunately untenable because the key oxidant $\mathrm{H}_{2} \mathrm{O}_{2}$ was 


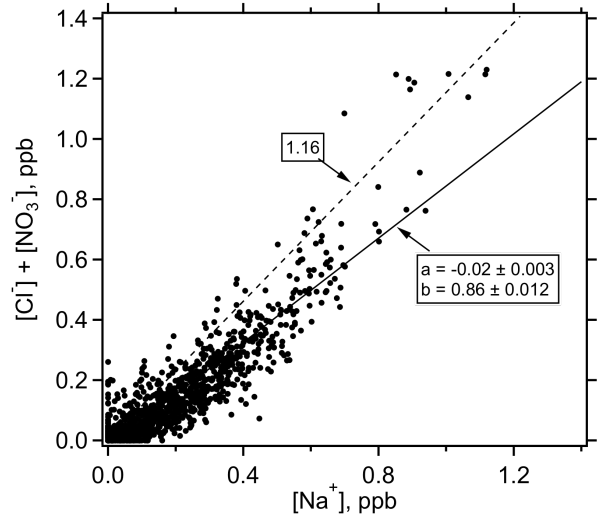

Figure 11. Relationship between concentrations of aerosol $\mathrm{Cl}^{-}$and $\mathrm{Na}^{+}$with $\mathrm{NO}_{3}^{-}$included to account for the displaced $\mathrm{Cl}^{-}$due to SSA acidification by $\mathrm{H}_{2} \mathrm{SO}_{4}$. The dash line represents the sea-water $\mathrm{Cl}^{-}$to $\mathrm{Na}^{+}$ratio of 1.16 , and the solid line a least square fit of the data whose intercept and slope are indicated.

not determined and the concentration of $\mathrm{SO}_{2}$ was always below the LOD of our instrument of $0.2 \mathrm{ppb}$.

\subsection{Composite longitudinal distributions of aerosol and gas constituents}

The composite longitudinal distributions of $\mathrm{SO}_{4}^{2-}, \mathrm{NH}_{4}^{+}$, and Org, as their LOWESS fits normalized to their maximum concentrations at the easternmost location (see, e.g., Fig. 5) are shown in Fig. 12a. Concentrations decreased steeply with distance from land indicating a continental origin. According to Allen et al. (2011, Fig. 4), 5-day back trajectories originating from $20^{\circ} \mathrm{S}$ show that for $72^{\circ} \mathrm{W}$ and $76^{\circ} \mathrm{W}$, land contact occurred at around $26-30^{\circ} \mathrm{S}$ and $30-40^{\circ} \mathrm{S}$ respectively, implying that substances sampled on the westernmost flight segments came from further south. However, since the back trajectories also show that the ages of the air masses sampled along the $19^{\circ} \mathrm{S}$ parallel since land contact were roughly comparable $(\sim 3-4$ days) because wind speeds were higher offshore than near the coast. Consequently we surmise that the longitudinal concentration gradients were due mainly to a higher degree of dilution with higher wind speed offshore. This dilution characteristic is roughly approximated by the normalized longitudinal distribution of the conservative tracer $\mathrm{CO}$ (Fig. 12a) provided the $\mathrm{CO}$ emission factor remained relatively invariant, and that an appropriate background value can be assigned. Regarding the latter, we chose $62 \mathrm{ppb}$, the average of the lowest $5 \%$ [CO], which is similar to the $61 \mathrm{ppb}$ used by Shank et al. (2012). Since background air can have different levels of $\mathrm{CO}$ depending on its history, choosing a single value to estimate the excess $\mathrm{CO}$ $\left([\mathrm{CO}]_{\mathrm{ex}}\right.$ ) has a relatively large uncertainty for regions of low total $[\mathrm{CO}]$. Finally, the fact that the highest $[\mathrm{CO}]_{\text {ex }}$ near the coast was only $\sim 14 \mathrm{ppb}$ indicates that a significant dilution
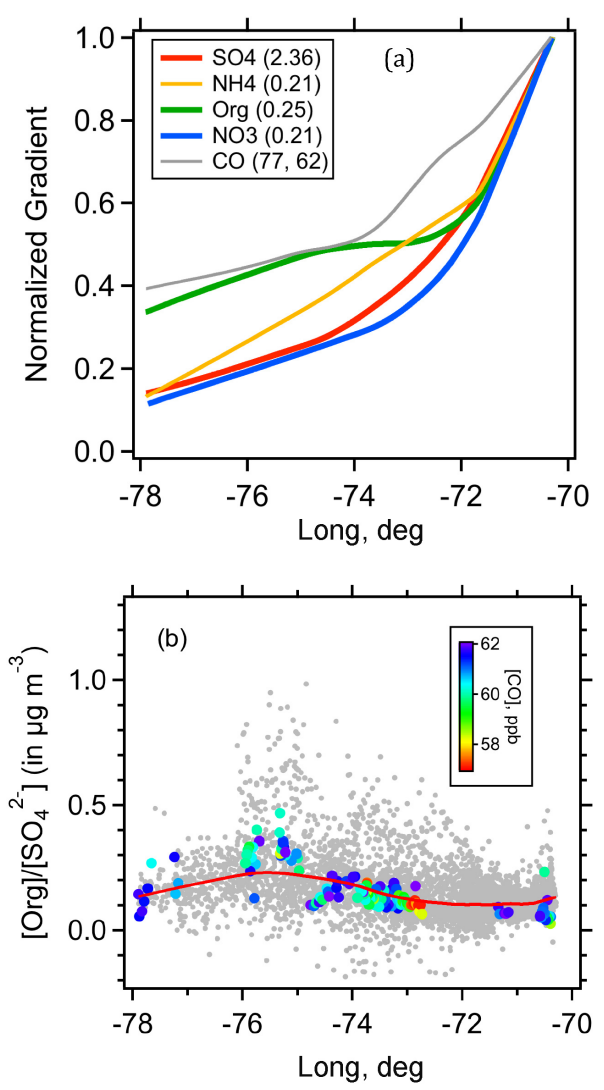

Figure 12. (a) Normalized composite longitudinal distributions of below-cloud $\mathrm{SO}_{4}^{2-}, \mathrm{NH}_{4}^{+}, \mathrm{Org}, \mathrm{NO}_{3}^{-}$, and $\mathrm{CO}$. The highest concentrations with which the LOWESS lines are normalized to are shown in the parentheses, all in $\mu \mathrm{g} \mathrm{m}^{-3}$ except for $\mathrm{CO}$ which is in ppb. The estimated background CO concentration is also indicated. (b) Dependence of $[\mathrm{Org}] /\left[\mathrm{SO}_{4}^{2-}\right]$ ratio on longitude, where the solid red line represents the LOWESS smooth of the data.

had occurred to the emissions from the sources considering a typical urban $[\mathrm{CO}]_{\mathrm{ex}}$ of $\sim 200 \mathrm{ppb}$ and greater.

The normalized median concentrations of aerosol $\mathrm{SO}_{4}^{2-}$, $\mathrm{NH}_{4}^{+}, \mathrm{NO}_{3}^{-}$, and Org all decreased with distance from the coast, but at different rates (Fig. 12a). Because the sampled air masses were fairly well aged and there was no appreciable production in the absence of additional sources over the MBL, the observed concentrations represented the amount remaining after dilution and removal. Regarding sulfur compounds, we note that the median $\left[\mathrm{SO}_{4}^{2-}\right]$ nearest the land $\left(70.4^{\circ} \mathrm{W}\right.$ ) was $2.5 \mu \mathrm{g} \mathrm{m}^{-3}$ (Fig. 3), corresponding to a $\left[\mathrm{SO}_{2}\right]=0.63 \mathrm{ppb}$. The mean gas phase $\left[\mathrm{SO}_{2}\right]$ reported by Yang et al. (2011) for the same longitude (at $20^{\circ} \mathrm{S}$ ) is $75 \mathrm{ppt}$, indicating that $\mathrm{SO}_{4}^{2-}$ production was near complete, accounting for $\sim 90 \%$ of the sulfur. $\left[S_{\mathrm{T}}\right] /[\mathrm{CO}]$ is estimated to be $\sim 0.705 / 14=0.05\left(S_{\mathrm{T}}=\mathrm{SO}_{2}+\mathrm{SO}_{4}^{2-}\right)$. At the westernmost point $\left(77.8^{\circ} \mathrm{W}\right)$, this ratio is decreased to $\sim 0.02$, using $[\mathrm{CO}]_{\mathrm{ex}} \sim 6 \mathrm{ppb},\left[\mathrm{SO}_{4}^{2-}\right] \sim 0.35 \mu \mathrm{g} \mathrm{m}^{-3}$, and $\left[\mathrm{SO}_{2}\right] \sim 30 \mathrm{ppt}$ 
(Yang et al., 2011), indicating that $\mathrm{SO}_{4}^{2-}$ loss was more extensive and that there was no apparent oceanic sulfur input.

For $\mathrm{NH}_{3}$, whose continental sources include combustion and biological processes (from south of the Atacama Desert), we expect it was quantitatively sequestered on the acidic $\mathrm{SO}_{4}^{2-}$ aerosols as $\mathrm{NH}_{4}^{+}$. Consequently, the fractional decrease of $\left[\mathrm{NH}_{4}^{+}\right]$with longitude should be identical to that of $\left[\mathrm{SO}_{4}^{2-}\right]$, which was found to be the case east of $71.5^{\circ} \mathrm{W}$ as these internally mixed aerosol components were diluted/removed together. If we consider that the emissions impacting this eastern region were dominated by combustion sources and had little biological input, a minimum emission factor of $\left[\mathrm{NH}_{3}\right] /[\mathrm{CO}] \sim 0.02\left(\mathrm{ppb} \mathrm{ppb}^{-1}\right)$ is estimated because of removal that has already taken place. However, west of $71.5^{\circ} \mathrm{W}$ an increased amount of $\mathrm{NH}_{4}^{+}$relative to $\mathrm{SO}_{4}^{2-}$ was observed peaking at $\sim 73.7^{\circ} \mathrm{W}$, suggesting additional sources in air masses from further to the south, either oceanic, continental, or both. We suggest that an oceanic source is plausible based on composite vertical distributions (see below). This increased $\mathrm{NH}_{4}^{+}$over $\mathrm{SO}_{4}^{2-}$ (Fig. 12a) causes an additional neutralization of the $\mathrm{SO}_{4}^{2-}$, raising the median $\left[\mathrm{NH}_{4}^{+}\right] /\left[\mathrm{SO}_{4}^{2-}\right]$ equivalents ratio from 0.25 to 0.3 .

Org also showed a fractional decay rate nearly identical to that of $\mathrm{SO}_{4}^{2-}$ east of $72^{\circ} \mathrm{W}$. The fact that Org decreased at a fractional rate identical to that of $\mathrm{SO}_{4}^{2-}$ east of $72^{\circ} \mathrm{W}$ is consistent with a scenario that $\mathrm{Org}$ and $\mathrm{SO}_{4}^{2-}$ aerosols were internally mixed. However, unlike $\mathrm{NH}_{4}^{+}$, [Org] will increase with photochemical age due to the formation of secondary organic aerosols (SOA) from gas phase precursors. Based on the CO emission factor, Kleinman et al. (2008) found a proportionality of $\sim 60 \mathrm{\mu g} \mathrm{m}^{-3}$ Org per ppm of CO in photochemically aged air applicable to urban emissions. The maximum estimated is $[\mathrm{Org}]_{\max } \sim 0.84 \mu \mathrm{g} \mathrm{m}^{-3}$ corresponding to $\mathrm{a}[\mathrm{CO}]_{\mathrm{ex}} \sim 14 \mathrm{ppb}$ at the easternmost location. Since the observed [Org] $\sim 0.25 \mu \mathrm{g} \mathrm{m}^{-3}$ was only $\sim 1 / 3$ of the estimated maximum, it appears that a large portion of the Org had already been removed from the aged air. But such apparent loss is associated with much uncertainty as it depends the similarity of $\mathrm{CO}$ emissions in Mexico City and those in Chile, and while we do not expect them to be vastly different, this is an unproven assumption.

Nitrate is a stable product of the oxidation of oxides of nitrogen and is the predominant nitrogen species in aged air. Aerosol $\mathrm{NO}_{3}^{-}$exhibited the same decay rate as $\mathrm{SO}_{4}^{2-}$ suggesting that the SSA on which $\mathrm{NO}_{3}^{-}$was absorbed was removed/diluted at the same rate as aerosol $\mathrm{SO}_{4}^{2-}$ for particles $D_{\mathrm{p}} \leq 1.5 \mu \mathrm{m}$. The fractional decay rates of $\mathrm{SO}_{4}^{2-}$ and $\mathrm{NO}_{3}^{-}$aerosols continue to track each other to $\sim 78^{\circ} \mathrm{W}$ with $\mathrm{SO}_{4}^{2-}$ showing a slight elevation over $\mathrm{NO}_{3}^{-}$between $72^{\circ} \mathrm{W}$ and $74^{\circ} \mathrm{W} ; \mathrm{CO}$ also revealed a slight increase between $72^{\circ} \mathrm{W}$ and $74^{\circ} \mathrm{W}$. Such variations were possibly due to variations in source attributes as back trajectory analysis indicates that source regions move further south as the sampling location moves westward.

We note that while $\mathrm{SO}_{4}^{2-}$ and $\mathrm{NO}_{3}^{-}$continue to decrease at approximately the same rates west of $\sim 72^{\circ} \mathrm{W}$, decay of Org slowed down significantly, reflecting additional sources of organic species relative to $\mathrm{SO}_{4}^{2-}$. This increase in Org is unlikely to result from entrainment of FT air since the median Org concentrations in the FT and the MBL were comparable, and the $\mathrm{MBL} \mathrm{SO}_{4}^{2-}$ to $\mathrm{NO}_{3}^{-}$ratio in this region did not vary (noting that $\mathrm{NO}_{3}^{-}$is essentially absent in the $\mathrm{FT}$ air). Because the transects west of $\sim 72^{\circ} \mathrm{W}$ received emissions from coastal regions south of $31^{\circ} \mathrm{S}$ (Allen et al., 2011) where biogenic emissions are expected, this increased OA (relative to $\mathrm{CO}$ ) over that observed on transect east of $\sim 72^{\circ} \mathrm{W}$ can be reasonably attributed to these continental sources. Although oceanic sources cannot be completely ruled out, we believe they play only a minor role, unless a higher productivity, west of $\sim 72^{\circ} \mathrm{W}$, can be supported. In fact, the lower ocean surface temperature associated with the high productivity upwelling zone found near the coast (Rahn and Garreaud, 2010) contradicts this possibility. The ratios of $[\mathrm{Org}] /\left[\mathrm{SO}_{4}^{2-}\right] \leq 0.08$ used to infer a marine origin by Shank et al. (2011) are shown in Fig. 12b as a function of longitude; the median $[\mathrm{Org}] /\left[\mathrm{SO}_{4}^{2-}\right]=0.13$ at $\sim 78^{\circ} \mathrm{W}$ corresponding to a median $[\mathrm{CO}]$ of $68 \mathrm{ppb}$, indicating significant land influence. For data points associated with [CO] $<62 \mathrm{ppb}$ (in color, Fig. 12b) we note most of the $[\mathrm{Org}] /\left[\mathrm{SO}_{4}^{2-}\right]$ ratios exceeded that suggested for a clean marine atmosphere for in the SEP region. We consider continental sources that had a minimal CO input, i.e., biogenic emissions from vegetation, are plausible.

\subsection{Composite vertical distributions of aerosol and gas constituents}

The LOWESS fits of the vertical distributions of $\mathrm{SO}_{4}^{2-}$, $\mathrm{NH}_{4}^{+}$, and Org in Fig. 5, normalized to their respective values at the lowest altitude are shown in Fig. 13. Even though these composites do not represent vertical distributions as would be obtained by soundings over a fixed location, insights regarding sources and transport of different species can be gained by comparing their relative trends.

In Fig. 13, $\mathrm{SO}_{4}^{2-}$ and Org display very similar vertical patterns in the lower MBL, but diverge in the upper MBL with $\mathrm{SO}_{4}^{2-}$ decreasing faster with altitude than Org. We attribute the similarity of their trends in the lower MBL to either coemission or co-located sources. The slower decrease of Org than $\mathrm{SO}_{4}^{2-}$ with altitude in the upper MBL (Fig. 13) could be due to the admixture of FT air, which was more enriched in Org than $\mathrm{SO}_{4}^{2-}$ (Fig. 5). However, the importance of this process can be ruled out based on the vertical distribution of SSA, which showed minimal influence in the FT. Two other possibilities include (1) in-cloud production (Blando and Turpin, 2000) favoring Org compared to $\mathrm{SO}_{4}^{2-}$, especially if $\mathrm{SO}_{2}$ had been depleted in the air that was sampled, 

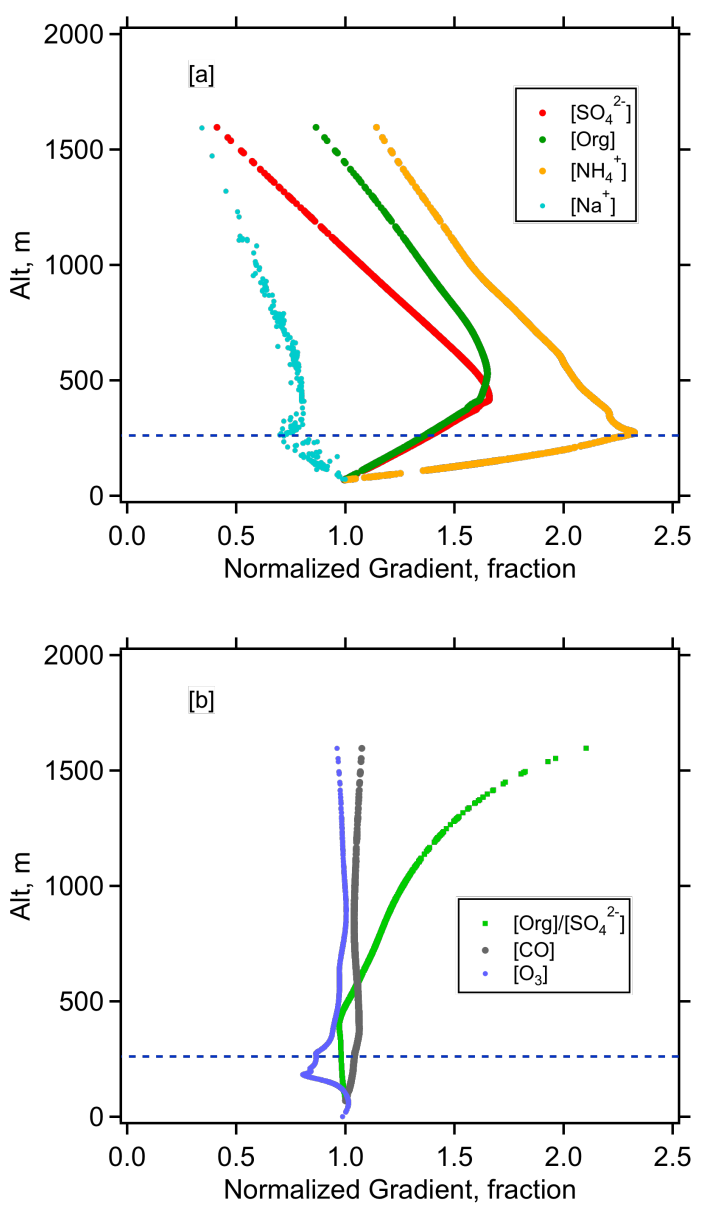

Figure 13. Normalized vertical distribution profiles of (a) $\mathrm{BC}$ aerosol $\mathrm{SO}_{4}^{2-}, \mathrm{NH}_{4}^{+}$, Org, and $\mathrm{Na}^{+}$; (b) $\mathrm{BC} \mathrm{O}_{3}$ and $\mathrm{CO}$ as well the $[\mathrm{Org}] /\left[\mathrm{SO}_{4}^{2-}\right]$ ratio.

and (2) a preferential removal of $\mathrm{SO}_{4}^{2-}$ over Org by precipitation if $\mathrm{SO}_{4}^{2-}$ and $\mathrm{Org}$ aerosols are externally mixed.

Although organic and $\mathrm{SO}_{4}^{2-}$ aerosols from urban and industrial sources are believed to be internally mixed, the extra OA from biogenic sources from coastal land south of $31^{\circ} \mathrm{S}$ has a potential to be externally mixed with anthropogenic $\mathrm{SO}_{4}^{2-}$ aerosols if primary $\mathrm{OA}$, such as that from biomass burn, dominates. Consequently, both possibilities are conceivable and it is not possible to assess their relative importance. On the other hand, $\mathrm{CO}$ and $\mathrm{O}_{3}$ were nearly uniformly distributed (Fig. 13b), consistent with their longer life times that allowed them to be well mixed in the MBL.

The vertical distribution of $\mathrm{NH}_{4}^{+}$showed an overall trend similar to $\mathrm{SO}_{4}^{2-}$ and $\mathrm{Org}$, but the slope of the increase with altitude in the lower MBL was larger than for $\mathrm{SO}_{4}^{2-}$. This observation is consistent with either a source or a sink of $\mathrm{NH}_{3}$ at the ocean surface. Since the $\mathrm{SO}_{4}^{2-}$ aerosols were strongly acidic, losing $\mathrm{NH}_{3}$ from the acidic $\mathrm{SO}_{4}^{2-}$ aerosol to the mildly basic seawater can be ruled out, and this sharper gradi- ent suggests an oceanic $\mathrm{NH}_{3}$ source. Positive sea-to-air $\mathrm{NH}_{3}$ flux has been observed for parts of the oceans (Johnson et al., 2008), especially in low latitude coastal regions with high productivity. We note that aerosol $\mathrm{NH}_{4}^{+}$showed a maximum at $\sim 260 \mathrm{~m}$, below that of $\mathrm{SO}_{4}^{2-}$, reflecting an optimum rate of sequestering of $\mathrm{NH}_{3}$ due to the maximum availability of both $\mathrm{SO}_{4}^{2-}$ aerosol and gaseous $\mathrm{NH}_{3}$. Above $\sim 260 \mathrm{~m}, \mathrm{NH}_{4}^{+}$ started to decrease as $\mathrm{NH}_{3}$ became the limiting reagent despite the continuous increase of $\mathrm{SO}_{4}^{2-}$ aerosol until $\sim 500 \mathrm{~m}$. Because the characteristic vertical mixing time of the MBL is relatively short, on the order of an hour, this oceanic $\mathrm{NH}_{3}$ source is expected to be close to the sampling location. The decrease in $\mathrm{NH}_{4}^{+}$with altitude in the upper MBL is slightly more gradual than for $\mathrm{SO}_{4}^{2-}$. This small increasing trend of $\left[\mathrm{NH}_{4}^{+}\right] /\left[\mathrm{SO}_{4}^{2-}\right]$ ratio indicates that in-cloud $\mathrm{SO}_{4}^{2-}$ production was not evident in the G-1 study region as $\mathrm{NH}_{4}^{+}$was conserved.

Distinct from $\mathrm{SO}_{4}^{2-}$ and $\mathrm{Org}$, SSA $\mathrm{Na}^{+}$(with $D_{\mathrm{p}} \leq 1.5 \mu \mathrm{m}$ ) exhibited a much more uniform vertical distribution with a small decreasing trend with altitude consistent with a surface source. Unlike continentally derived aerosols, which exhibit a strong land to sea gradient, SSA loading in the MBL remained relatively constant with longitude and for this reason the composite vertical profile is less prone to sampling biases. The $\mathrm{Na}^{+}$vertical profile exhibited a small minimum at $\sim 260 \mathrm{~m}$ that corresponded to a small maximum in the profiles of both water mixing ratio and potential temperature, but not in that of $\mathrm{SO}_{4}^{2-}$ and Org. We believe this apparent "inversion" is an artifact due to the sampling pattern, and does not reflect a true physical layering.

\subsection{Cloud processing}

Here we compare particle size distributions measured by the DMA during the return legs in the MBL on the flights of 28 October 2008 and 6 November 2008 to provide evidence that differences in the size distribution and their longitudinal dependency between the two flights are due to differences in the amount of cloud processing. Particle size distributions for the two flights binned into 1-degree longitude are shown in Fig. 14. The data from both flights exhibited the bi-modal distribution expected for cloud processing consistent with the composite distribution of the entire G-1 mission (Kleinman et al., 2012), with the exception of those sampled closest to the coast on both flights. We consider the size distribution observed between $71^{\circ} \mathrm{W}$ and $72^{\circ} \mathrm{W}$ to be representative of the emissions impacting the MBL observed on this flight westward of this longitude based on the similarity in mode sizes and concentration levels. The much higher Aitken mode particle concentrations compared to the droplet mode reflects the emission characteristics as well as the limited cloud processing due to both a shorter processing time and a tendency for fewer clouds in the mid-afternoon near 
the coast when they were sampled. The particle size distributions from east to west on 28 October 2008 were highly uniform evidenced by a near constant droplet mode size at $0.18 \mu \mathrm{m}$ and a progressively smaller Aitken mode size from $\sim 0.06$ to $\sim 0.04 \mu \mathrm{m}$, reflecting emissions with similar characteristics that were more extensively processed and diluted going west along the $\sim 19^{\circ} \mathrm{S}$ parallel. The spectrum for the westernmost section, $77-77.3^{\circ} \mathrm{W}$, showed some cloud contamination reflected in the increased small size particles from shattering, which however did not affect the mode sizes. In comparison, the data of 6 November 2008 showed still less processed emissions between $71^{\circ} \mathrm{W}$ and $72^{\circ} \mathrm{W}$ indicated by the much higher Aitken mode particle concentrations compared to that of the droplet mode with only a slight hint of the Hoppel minimum (Hoppel et al., 1986). The Aitken mode size decreased progressively from $\sim 0.07 \mu \mathrm{m}$ to $\sim 0.04 \mu \mathrm{m}$ from east to west similar to that observed on 28 October 2008. Regarding droplet mode particle size distributions, we note the concentrations decreased rapidly and steadily from east to west on 28 October 2008, but this decrease was much less pronounced on 6 November 2008 (Fig. 16). We surmise this rather steady droplet mode particle concentrations observed on 6 November 2008 across a wide longitude range was due to a more extensive cloud processing, growing more particles into the larger particle size range. The lower WS on 6 November 2008 compared to that of 28 October 2008 could allow a more extensive cloud processing because of an increased transport and reaction time. Finally, the droplet mode particle size is seen to decrease with distance from the coast on 6 November 2008, noting that while the left edges of the peaks were tightly clustered together, the right edges steadily retracted. In contrast, the droplet mode particle size observed on 28 October 2008 remained roughly constant as the number concentrations steadily decreased from east to west. We attribute this size shift observed on 6 November 2008 to the loss of larger sized particles to precipitation because, all things equal, larger particles will be activated at lower supersaturations than smaller ones and lost through precipitation scavenging, which may also be consistent with a more extensive cloud processing.

\section{Conclusions}

The chemical composition of accumulation mode aerosol particles in coastal marine atmospheres off northern Chile was determined on board the DOE G-1 using an AMS and the PILS-IC during 2008 VOCALS-REx. Strongly acidic sulfate aerosols, which were on average only $25 \%$ neutralized by $\mathrm{NH}_{3}$, dominated all other aerosol constituents, accounting for $\geq 50 \%$ of the total aerosol mass concentration; total organic aerosol $(\mathrm{Org})$ and $\mathrm{NH}_{4}^{+}$each contributed $<15 \%$. Aerosol $\mathrm{NO}_{3}^{-}$was found to reside on SSA particles externally mixed with $\mathrm{SO}_{4}^{2-}$ particles, resulting from uptake of gaseous $\mathrm{HNO}_{3}$ by SSA giving rise to a portion of the
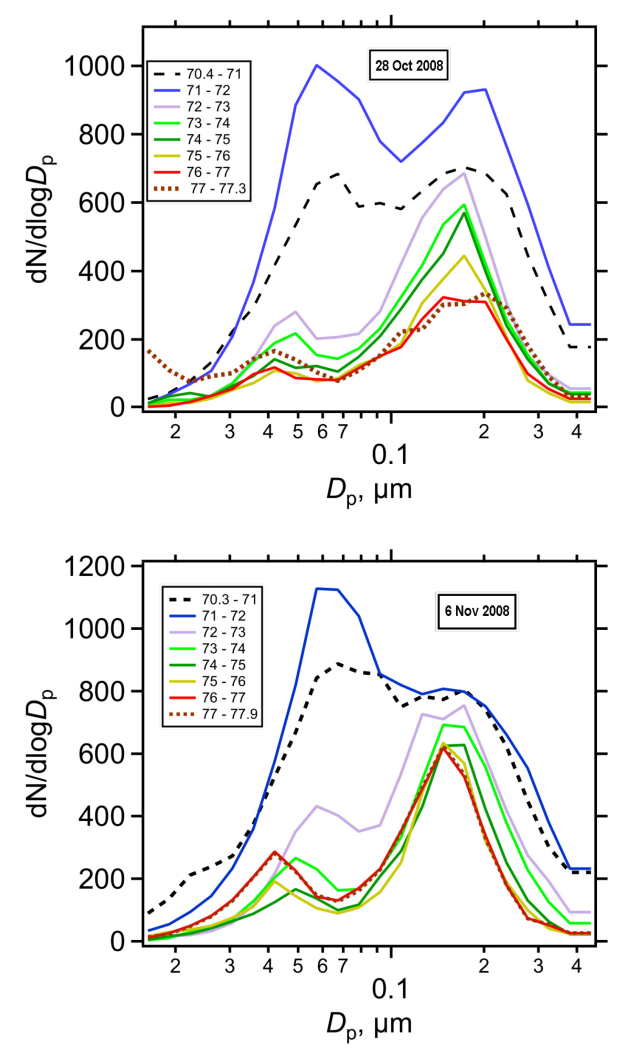

Figure 14. MBL aerosol particle size distributions during return legs on 28 October 2008 and 6 November 2008 as a function of longitude with data binned into $1^{\circ}$ intervals.

observed chloride deficit. Concentrations of MBL aerosol $\mathrm{SO}_{4}^{2-}, \mathrm{NH}_{4}^{+}$, Org, and $\mathrm{NO}_{3}^{-}$all exhibited a strong longitudinal gradient decreasing with distance from the coast, consistent with their continental origins. In contrast, SSA loading represented by $\mathrm{Na}^{+}$was fairly uniform in the MBL with a slight increase offshore where wind speeds were higher. The observed SSA mass loading agreed with the canonical wind speed dependence reported in the literature; the coastal surf zone SSA production was found to contribute to SSA loading at distances as far as to $\sim 400 \mathrm{~km}$ offshore. The estimated number concentration of SSA was much smaller than that for $\mathrm{SO}_{4}^{2-}$ aerosols even at $\sim 78^{\circ} \mathrm{W}, \sim 800 \mathrm{~km}$ from the coast. Accumulation mode SSA loading showed a uniform vertical distribution and can in principle be used as a tracer to assess the extent of dilution of MBL due to entrainment of FT air. MSA, an oxidation product of DMS, was mostly below the detection limit of the PILS, indicating a minimal role played by DMS from the ocean in sulfur chemistry within the G-1 study domain. Relative changes in distribution patterns in simultaneously measured aerosol species suggest that sources beyond those from urban and industrial regions exist for $\mathrm{NH}_{3}$, likely of oceanic origin, and for OA, likely from continental biogenic sources south of Atacama Desert. In contrast, concentrations of $\mathrm{MBL}$ aerosol $\mathrm{NO}_{3}^{-}$and $\mathrm{SO}_{4}^{2-}$ 
tracked each other and appeared to be entirely attributable to continental anthropogenic emissions that were co-emitted or co-located. Analysis of aerosol size distributions on 28 October 2008 and 6 November 2008 was consistent with more extensive cloud processing on the latter flight.

Acknowledgements. The Atmospheric Sciences Program within the DOE Office of Biological and Environmental Research, which has since been merged into the Atmospheric System Research Program, supported this research. The authors gratefully acknowledge the DOE G-1 flight crew led by Chief Pilot Bob Hannigan for their dedication and professionalism that ensured a safe and productive scientific mission.

Edited by: R. Wood

\section{References}

Allen, G., Coe, H., Clarke, A., Bretherton, C., Wood, R., Abel, S. J., Barrett, P., Brown, P., George, R., Freitag, S., McNaughton, C., Howell, S., Shank, L., Kapustin, V., Brekhovskikh, V., Kleinman, L., Lee, Y.-N., Springston, S., Toniazzo, T., Krejci, R., Fochesatto, J., Shaw, G., Krecl, P., Brooks, B., McMeeking, G., Bower, K. N., Williams, P. I., Crosier, J., Crawford, I., Connolly, P., Allan, J. D., Covert, D., Bandy, A. R., Russell, L. M., Trembath, J., Bart, M., McQuaid, J. B., Wang, J., and Chand, D.: South East Pacific atmospheric composition and variability sampled along $20^{\circ} \mathrm{S}$ during VOCALS-REx, Atmos. Chem. Phys., 11, 5237-5262, doi:10.5194/acp-11-5237-2011, 2011.

Blando, J. D. and Turpin, B. J.: Secondary organic aerosol formation in cloud and fog droplets: a literature evaluation of plausibility, Atmos. Environ., 34, 1623-1632, 2000.

Blot, R., Clarke, A. D., Freitag, S., Kapustin, V., Howell, S. G., Jensen, J. B., Shank, L. M., McNaughton, C. S., and Brekhovskikh, V.: Ultrafine sea spray aerosol over the southeastern Pacific: open-ocean contributions to marine boundary layer CCN, Atmos. Chem. Phys., 13, 7263-7278, doi:10.5194/acp-137263-2013, 2013.

Brechtel, F.: Description and assessment of a new aerosol inlet system for the DOE G-1 Research Aircraft, Technical Report, Brechtel Manufacturing, Inc., 2002.

Bretherton, C. S., Wood, R., George, R. C., Leon, D., Allen, G., and Zheng, X.: Southeast Pacific stratocumulus clouds, precipitation and boundary layer structure sampled along $20^{\circ} \mathrm{S}$ during VOCALS-REx, Atmos. Chem. Phys., 10, 10639-10654, doi:10.5194/acp-10-10639-2010, 2010.

Canagaratna, M. R., Jayne, J. T., Jimenez, J. L., Allan, J. D., Alfarra, M. R., Zhang, Q., Onasch, T. B., Drewnick, F., Coe, H., Middlebrook, A., Delia, A., Williams, L. R., Trimborn, A. M., Northway, M. J., DeCarlo, P. F., Kolb, C. E., Davidovits, P., and Worsnop, D. R.: Chemical and microphysical characterization of ambient aerosols with the aerodyne aerosol mass spectrometer, Mass Spectrom. Rev., 26, 185-222, doi:10.1002/mas.20115, 2007

Chand, D., Hegg, D. A., Wood, R., Shaw, G. E., Wallace, D., and Covert, D. S.: Source attribution of climatically important aerosol properties measured at Paposo (Chile) during VO-
CALS, Atmos. Chem. Phys., 10, 10789-10801, doi:10.5194/acp10-10789-2010, 2010.

Cleveland, W. S.: Robust locally weighted regression and smoothing scatterplots, J. Am. Stat. Assoc., 74, 829-836, 1979.

Drewnick, F., Hings, S. S., DeCarlo, P., Jayne, J. T., Gonin, M., Fuhrer, K., Weimer, S., Jimenez, J. L., Demerjian, K. L., Borrmann, S., and Worsnop, D. R.: A New Time-of-Flight Aerosol Mass Spectrometer (TOF-AMS) - Instrument Description and First Field Deployment, Aerosol Sci. Tech., 39, 637658, doi:10.1080/02786820500182040, 2005.

Hawkins, L. N., Russell, L. M., Covert, D. S., Quinn, P. K., and Bates, T. S.: Carboxylic acids, sulfates, and organosulfates in processed continental organic aerosol over the southeast $\mathrm{Pa}$ cific Ocean during VOCALS-Rex 2008, J. Geophys. Res., 115, D13201, doi:10.1029/2009JD013276, 2010.

Hoppel, W. A., Frick, G. M., and Larson, R. E.: Effect of nonprecipitating clouds on the aerosol size distribution in the marine boundary layer, Geophys. Res. Lett., 13, 125-128, doi:10.1029/GL013i002p00125, 1986.

Johnson, M. T., Liss, P. S., Bell, T. G., Lesworth, T. J., Baker, A. R., Hind, A. J., Jickells, T. D., Biswas, K. F., Malcolm, E., Woodward, S., and Gibb, S. W.: Field observations of the ocean-atmosphere exchange of ammonia: Fundamental importance of temperature as revealed by a comparison of high and low altitudes, Global Geochem. Cy., 22, GB1019, doi:10.1029/2007GB003039, 2008.

Kawakami, N., Osada, K., Nishita, C., Yabuki, M., Kobayashi, H., Hara, K., and Shiobara, M.: Factors controlling sea salt modification and dry deposition of nonsea-salt components to the ocean, J. Geophys. Res., 113, D14216, doi:10.1029/2007JD009410, 2008.

Kleinman, L. I., Springston, S. R., Daum, P. H., Lee, Y.-N., Nunnermacker, L. J., Senum, G. I., Wang, J., Weinstein-Lloyd, J., Alexander, M. L., Hubbe, J., Ortega, J., Canagaratna, M. R., and Jayne, J.: The time evolution of aerosol composition over the Mexico City plateau, Atmos. Chem. Phys., 8, 1559-1575, doi:10.5194/acp-8-1559-2008, 2008.

Kleinman, L. I., Daum, P. H., Lee, Y.-N., Lewis, E. R., Sedlacek III, A. J., Senum, G. I., Springston, S. R., Wang, J., Hubbe, J., Jayne, J., Min, Q., Yum, S. S., and Allen, G.: Aerosol concentration and size distribution measured below, in, and above cloud from the DOE G-1 during VOCALS-REx, Atmos. Chem. Phys., 12, $207-$ 223, doi:10.5194/acp-12-207-2012, 2012.

Lewis, E. R. and Schwartz, S. E.: Sea Salt Aerosol Production: Mechanisms, Methods, Measurements and Models, Geophysical Monograph Series Vol. 152, American Geophysical Union, Washington, DC, 413 pp., 2004.

O’Dowd, C. D., Facchini, M. C., Cavalli, F., Ceburnis, D., Mircea, M., Decesari, S., Fuzzi, S., Yoon, Y. J., and Putaud, J.-P.: Biogenically driven organic contribution to marine aerosol, Nature, 431, 676-680, 2004.

Orsini, D. A., Ma, Y., Sullivan, A., Sierau, B., Baumann, K., and Weber, R. J.: Refinements to the particle-into-liquid sampler (PILS) for ground and airborne measurements of water soluble aerosol composition, Atmos. Environ., 37, 1243-1259, 2003.

Rahn, D. A. and Garreaud, R.: Marine boundary layer over the subtropical southeast Pacific during VOCALS-REx - Part 1: Mean structure and diurnal cycle, Atmos. Chem. Phys., 10, 4491-4506, doi:10.5194/acp-10-4491-2010, 2010. 
Shank, L. M., Howell, S., Clarke, A. D., Freitag, S., Brekhovskikh, V., Kapustin, V., McNaughton, C., Campos, T., and Wood, R.: Organic matter and non-refractory aerosol over the remote Southeast Pacific: oceanic and combustion sources, Atmos. Chem. Phys., 12, 557-576, doi:10.5194/acp-12-557-2012, 2012.

Springston, S. R., Kleinman, L. I., Nunnermacker, L. J., Brechtel, F., Lee, Y.-N., and Wang, J.: Chemical evolution of an isolated power plant plume during the TexAQs 2000 study, Atmos. Environ., 39, 3431-3443, 2005.

Tomlinson, J. M., Li, R., and Collins, D. R.: Physical and chemical properties of the aerosol within the southeastern Pacific marine boundary layer, J. Geophys. Res., 112, D12211, doi:10.1029/2006JD007771, 2007.

Wang, J., Flagan, R. C., and Seinfeld, J. H.: A Differential Mobility Analyzer (DMA) System for Submicron Aerosol Measurements at Ambient Relative Humidity, Aerosol Sci. Tech., 37, 46-52, doi:10.1080/02786820300891, 2003.

Wood, R., Mechoso, C. R., Bretherton, C. S., Weller, R. A., Huebert, B., Straneo, F., Albrecht, B. A., Coe, H., Allen, G., Vaughan, G., Daum, P., Fairall, C., Chand, D., Gallardo Klenner, L., Garreaud, R., Grados, C., Covert, D. S., Bates, T. S., Krejci, R., Russell, L. M., de Szoeke, S., Brewer, A., Yuter, S. E., Springston, S. R., Chaigneau, A., Toniazzo, T., Minnis, P., Palikonda, R., Abel, S. J., Brown, W. O. J., Williams, S., Fochesatto, J., Brioude, J., and Bower, K. N.: The VAMOS Ocean-Cloud-AtmosphereLand Study Regional Experiment (VOCALS-REx): goals, platforms, and field operations, Atmos. Chem. Phys., 11, 627-654, doi:10.5194/acp-11-627-2011, 2011.
Yang, M., Huebert, B. J., Blomquist, B. W., Howell, S. G., Shank, L. M., McNaughton, C. S., Clarke, A. D., Hawkins, L. N., Russell, L. M., Covert, D. S., Coffman, D. J., Bates, T. S., Quinn, P. K., Zagorac, N., Bandy, A. R., de Szoeke, S. P., Zuidema, P. D., Tucker, S. C., Brewer, W. A., Benedict, K. B., and Collett, J. L.: Atmospheric sulfur cycling in the southeastern Pacific longitudinal distribution, vertical profile, and diel variability observed during VOCALS-REx, Atmos. Chem. Phys., 11, 50795097, doi:10.5194/acp-11-5079-2011, 2011.

Yin, F., Grosjean, D., and Seinfeld, J. H.: Photooxidation of dimethyl sulfide and dimethyl disulfide. I: Mechanism development, J. Atmos. Chem., 11, 309-364, 1990. 